\title{
Transmission of Monetary Policy in Times of High Household Debt
}

\author{
Youngju Kim*, Hyunjoon Lim**
}

The views expressed herein are those of the authors and do not necessarily reflect the official views of the Bank of Korea. When reporting or citing this paper the authors' names should always be explicitly stated.

* Senior Economist, Macroeconomics Team, Economic Research Institute, The Bank of Korea, Tel: +82-2-759-5475, E-mail: econoky@bok.or.kr.

** Senior Economist, International Economics Team, Economic Research Institute, The Bank of Korea, Tel: +82-2-759-5427, E-mail: limhj1@bok.or.kr.

The authors are grateful to Wook Sohn, Byung Kwun Ahn, Jiyoon Oh, Kyung Keun Kim, an anonymous reviewer and the participants at the interim seminar and BOJ-BOK Research Workshop for their valuable comments and suggestions. 


\section{Contents}

I . Introduction …………………………………………………… 1

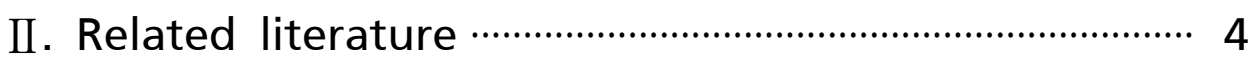

III. Data and Methodology …………………………………... 6

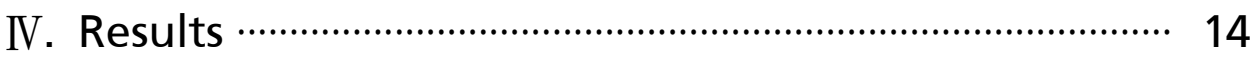

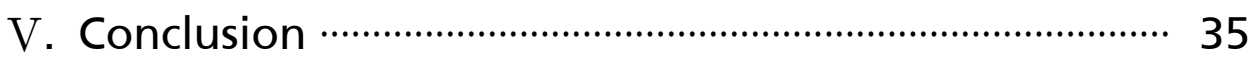

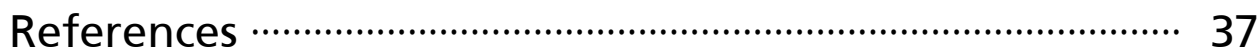




\section{Transmission of Monetary Policy in Times of High Household Debt}

This paper explores whether the effectiveness of monetary policy can be affected by the degree of household indebtedness. We take an interacted panel VAR approach using a panel of 28 countries and thereby obtain several interesting findings. That is, the responses of consumption and investment to monetary shocks are stronger in the state of high household debts. Such responses furthermore become larger in a contractionary monetary policy stance rather than in an expansionary one. Finally, we find that the negative impact of contractionary monetary shocks on the real economy is stronger in the countries with a higher share of adjustable rate loans. We conjecture that these findings lend support for the presence of "cash flow channel" with respect to the transmission of contractionary monetary policy.

Keywords: Household debt, Monetary policy, Interacted panel VAR, Adjustable-rate loans

JEL Classification Numbers: E52, E62, R38 


\section{Introduction}

Despite unconventional monetary policy measures in major advanced economies following the Global Financial Crisis (GFC), the pace of global recovery has been slow and tepid since the crisis. Such a disappointing recovery has raised questions over the effectiveness of monetary policy in helping economies overcome the Great Recession. In this regard, one strand of literature focuses on the factors that have prevailed during the recovery period to explain the reasons behind the weakening of monetary policy effectiveness; the other strand investigates the state-dependent nature of monetary policy effectiveness anew. ${ }^{1)}$

Some of the recent literature on these issues point to household indebtedness as a state that may determine the effectiveness of monetary policy. From theoretical perspectives, the high level of household indebtedness may reinforce the effects of monetary policy on real economic activities. First, the so-called "cash-flow" channel of monetary policy2) explains that in the case of highly-indebted households, the same change in the policy rate can have a larger effect on households' interest burden, and thus, on their after-interest income and expenditures (Floden et al., 2016; Cloyne et al., 2016). Second, the financial accelerator mechanism by Kiyotaki and Moore (1997), and Bernanke et al. (1999) implies that the effect of monetary policy is likely to be more amplified when households hold high debts, most of which are related to housing mortgages. For instance, the same change in the policy rate can have a larger impact on households' net worth when they have high debts and subsequently show a higher housing level.

In contrast, there are some reasons to think that monetary policy has a

1) Economic factors arising in the wake of balance sheet recessions, which may undermine monetary policy effectiveness, include household debt overhang, impaired financial sector, low confidence and heightened uncertainty, low productivity growth, Zero lower bound on the policy rate and etc. See Borio and Hofmann (2016) for more details.

2) Monetary policy can have a direct effect on household spending via its effect on households' cash flow and disposable income. In this channel, the dominant type of interest rate contracts - fixed versus floating interest rates - that apply to house debt is likely to matter. 
smaller impact when households have the high level of debts in the context of the US recent recession. Mian and Sufi $(2014,2015)$ argue that the precautionary savings motive, induced by the heightened risk to future employment income and low equity mortgages, renders high-leveraged households less responsive to monetary stimulus during the balance sheet recession associated with the crisis. From a theoretical perspective, Alpanda and Zubairy (2016), with a partial equilibrium model where households are financially constrained, argue that the cash-flow channel of monetary policy is stronger in a high debt state, but new borrowing through home equity loans (i.e. home-equity loan channel) works only when debt levels are relatively low and borrowers hold an adequate level of home equity.3) They argue that expansionary monetary policy may have a weaker effect under high levels of debts, when the effect of the home equity channel dominates that of the cash-flow channel. Also, Bhutta and Keys (2016) show that low home equity levels make it more difficult for households to tap into their home equity lines of credit. In the similar vein, Chen et al. (2013) and Beraja et al. (2015) find evidence that households with low home equity levels have difficulties in refinancing at a lower mortgage rate.

In this paper, we investigate whether household indebtedness affects the effectiveness of monetary policy, using a panel of 28 countries covering the period of 1984:Q1 to 2015:Q4. In this process, we estimate the asymmetric effect of monetary policy depending on the direction of policy stance as well as the level of household indebtedness, departing from the existing related literature, most of which focuses on the average effect of monetary shocks with opposite signs. In addition, we attempt to examine the cash-flow channel in the transmission of monetary policy shocks, exploiting the cross-country difference in the predominant type of interest rate contracts that apply to household debts. If a country is dominated by fixed-rate mortgages (FRMs), one would expect the cash-flow channel to be muted. However, in economies where most mortgages have an adjustable

3) In their model, households first use rising housing equity values induced by expansionary monetary policy to reduce leverage in the high debt state, by letting the debt-to-equity ratio fall, before they start to borrow again. 
rate (ARMs), the cash-flow channel may be important for the transmission of monetary policy.

In our empirical analyses, we utilize an interacted Panel Vector Auto Regression (IPVAR), introduced by Towbin and Weber (2012) and Sa et al. (2014), as a framework to test whether household indebtedness affects the effectiveness of monetary policy. IPVAR allows VAR coefficients to vary as a deterministic function of observable economic characteristics, and thereby enables us to examine the impact of economic characteristics on the transmission mechanism of an economic shock of interest. We estimate a PVAR and augment it with an interaction term that allows the estimated coefficients to vary with the level of household indebtedness. With this approach, we can investigate how the impulse response of macroeconomic variables to a monetary shock varies with the level of household indebtedness. In addition to the strength of monetary policy depending upon household indebtedness, monetary policy may have an asymmetric effect based on its stance - expansionary or contractionary. To test for the possible asymmetric effect of monetary policy, we extend the interaction term to allow the effect of monetary policy to depend on both the direction of monetary policy and household indebtedness. In this framework, we can test the asymmetric effect of monetary policy across the state of household indebtedness. Lastly, we split the sample countries into the two groups by the predominant type of interest rate that applies to household debt - floating vs fixed interest rate contracts - in order to study the validity of the cash-flow channel of monetary policy. Then we estimate the Panel VAR with the extended interaction term for each group, respectively, and compare the impulse responses to monetary policy stance.

Our first findings suggest that monetary policy have a stronger average effect on real economic activities, in particular consumption and investment, when households are highly indebted. This result does not discriminate between an expansionary and a contractionary monetary policy stance. We disentangle the effect of contractionary and expansionary policy shocks on output and prices in a high debt state and find that contractionary 
monetary policy has a stronger effect on consumption and investment than expansionary policy. Finally, we investigate whether the effect of contractionary monetary policy in a high debt state results from the type of interest rate contracts, and discover that the negative impact of contractionary monetary shocks on the real economy is stronger in countries with a higher share of adjustable-rate loans. This finding is in line with what the cash flow channel implies - monetary policy is more powerful when households are highly indebted and have adjustable rate contracts. Our results, however, imply that the cash flow channel may be more responsive to contractionary monetary policy.

The remainder of this paper is organized as follows. The next section discusses the related literature. Section 3 describes the data, presents the empirical methodology. In Section 4, baseline estimates of impulse responses with several extensions are reported together with the results from various robustness checks. Section 5 concludes.

\section{Realted Literature}

This paper relates to several strands of literature. First, we contribute to the literature studying on the state dependence of the effectiveness of monetary policy ${ }^{4}$ and, in particular, to the literature on the relation between the level of household indebtedness and the effectiveness of monetary policy. The existing empirical literature on how the impact of monetary policy varies with household indebtedness is very few. Alpanda and Zubairy (2016) show that the effect of US monetary policy is less powerful in a state where the level of household debt is relatively high. They attribute a decline in monetary policy effectiveness to the weakening of the home equity loan channel due to the deleveraging of household

4) Previous research focuses on how the effect of monetary policy varies with the business cycle. Previous tests have had somewhat mixed results. Lo and Piger (2005), Garcia and Schaller (2002), and Weisse (1999) find that US monetary policy has a greater impact on output during recessions. However, more recently, Tenreyro and Thwaites (2016) find that the effect of US monetary policy is less powerful in recessions. Also see Smets and Peerman (2005) and Thoma (1994). 
debt in a high debt state. Beraja et al. (2015) employ the U.S. loan-level data and show that expansionary monetary policy following the crisis shows a weaker impact when home equity levels are low.

Second, our work is related to the literature on the asymmetric effect of monetary policy in terms of the direction of monetary policy shocks. Tenreyro and Thwaites (2016), Angrist et al. (2013), and Cover (1992) find evidence that contractionary monetary shocks are more powerful than expansionary shocks to output and prices.5) Barnichon and Matthes (2016) develop a Gaussian Mixture approximation approach to estimate whether monetary policy shocks generate asymmetric responses upon the direction of shocks as well as the state of economy. They find that expansionary monetary policy has a weaker effect on unemployment than contractionary policy. In addition, they suggest evidence that the effect of expansionary policy rests on the state of unemployment: expansionary monetary policy has a greater impact on unemployment in the period of high unemployment. Santoro et al. (2014) develop a dynamic general equilibrium model where households' utility depends on consumption deviations from a reference level, below which loss aversion is displayed; thus, they reproduce an empirically relevant asymmetry in the reaction of output to monetary policy shocks with opposite signs: contractionary monetary policy shocks have greater effects on output, compared with expansionary shocks.

Third, our findings complement evidence from a growing literature on the relation between household debts and the transmission mechanisms of monetary policy, in particular, the cash-flow channel. For instance, using the registry-based data on Swedish households, Floden et al. (2016) suggest evidence that monetary policy will have a stronger effect on real economic activities when households are highly indebted with adjustable rate mortgages. Cloyen et al. (2016) study the response to and income on monetary policy in the U.K. and the U.S. They insist that the dollar

5) Tenreyro and Thwaites (2016) also suggest evidence that the effect of monetary policy is less powerful in recessions, insisting that asymmetric effects of monetary policy shocks with opposite signs cannot be the source of asymmetry across the business cycle given that contractionary and expansionary monetary shocks are equally common in both booms and recessions. 
change in mortgage payments following a temporary rate cut of 25bp is three times as large in the U.K., in which most mortgages have an adjustable rate in contrast to the U.S. However, they argue that the general equilibrium effect of the rate cut on income is quantitatively more important than the direct effect of cash-flows. Calza et al. (2013) show that the transmission mechanism of monetary shocks to consumption is stronger in countries with a higher debt to GDP ratio and a higher share of adjustable rate mortgages. Rubio (2011) builds a model with the housing market and collateral-constrained households, extending the framework in Iacoviello (2005) by allowing for both adjustable and fixed rate mortgages. Monetary policy has a stronger effect when a larger share of mortgages has adjustable rates. However, in general equilibrium, the partial equilibrium effects are muted by there distribution between borrowers and savers as well as by labor supply responses. Garriga et al. (2015) find that monetary policy shocks have a larger real effect under ARMs than FRMs since an increase in interest rates reduces consumption growth not only through a reduction in new borrowings but also by increasing mortgage payments.

\section{Data and Methodology}

\section{Model Identification}

Our model is based on the interacted panel VAR methodology which is pioneered by Towbin and Weber (2012) and Sá et al. (2014). This model allows for the interaction between the endogenous variables and exogenous terms, thereby exploring dynamics varying with exogenous circumstances. That is, we attempt to investigate the effectiveness of monetary policy in a varying degree of household indebtedness. Furthermore, we test for the asymmetry in the cyclical response to a monetary policy shock by plugging additional interaction terms, dummies of identifying a monetary policy stance. Lastly, we split the sample into the two country groups, utilizing 
the predominant type of interest rate that applies to household debts for each country in order to empirically test the hypothesis that a higher share of adjustable interest loans may amplify the impact of monetary policy on the macroeconomy.

We begin by estimating the transmission of monetary policy, using a simple PVAR model without interactive terms. The PVAR model is given by:

$$
A_{i, t} y_{i, t}=A_{i, 0}+\sum_{p=1}^{P} A_{i, t-p} y_{i, t-p}+\varepsilon_{i, t}
$$

where $y_{i, t}$ is a $K \times 1$ vector containing endogenous variables, and $t=1, \cdots \cdots, T$ and $i=1, \cdots \cdots, N$ denote time and sample country, respectively. The $K \times K$ matrices $A_{i, t-p}$ where $p=0,1, \cdots, P$ contain contemporaneous and autoregressive relationships between all endogenous variables, respectively. $A_{i, 0}$ is a country-specific intercept, which corresponds to the fixed effect in the panel regression. The $K \times 1$ vector of structural residuals $\varepsilon_{i, t}$ is normally distributed with a mean of zero and with a diagonal $K \times K$ covariance matrix $\sum$. In particular, we allow for heterogeneous slope parameters $A_{i, p}$ across countries as well as country-specific intercepts $A_{i, 0}$, which is in line with Sá et al. (2014).6)

The panel VAR is now augmented with interactive terms between endogenous variables. As a means of testing for the implication of the level of household debt on the effectiveness of monetary policy, we need to set up an alternative specification of the PVAR model that explicitly allows for the time-varying level of household debt as an exogenous factor acting on the response of real sector variables and prices to a monetary policy shock to control for potentially related variables. Toward this end, we impose that the autoregressive coefficients of endogenous variables are the functions of the cross-time-varying level of household debt-to-GDP ratio. Such frameworks have been first proposed by Loayza and Raddatz

6) Pesaran and Smith (1995) show that assuming homogeneity in slope parameters across countries can have negative consequences: for large $\mathrm{T}$ and $\mathrm{N}$, imposing only heterogeneity in intercepts may result in inconsistency. 
(2007) and Towbin and Weber (2013), allowing to evaluate whether the macroeconomic response to policy shocks varies with exogenous structural characteristics. We consider interactive terms such that the coefficients in (1) are given by:

$$
A_{i, t}=\alpha_{o, p}+\alpha_{1, p} X_{i, t-p-1}
$$

where $X_{i, t-p-1}$ is a matrix of country characteristics which are expected to affect the response of macroeconomic variables to monetary policy shocks; and $\alpha_{1, p}$ is a vector of coefficients and varies over time and across countries with the degree of interaction variables.

Specifically, as noted above, we utilize household debt in the form of a percentage of GDP of the previous four-quarter moving average, as the main interaction variable in the baseline estimation as follows:

$$
A_{i, t-p}=\alpha_{0, p}+\alpha_{1, p} M A_{4}\left[\left(\frac{H D}{G D P}\right)_{i, t-p-1}\right]
$$

where $t=1, \cdots \cdots, T$ and $i=1, \cdots \cdots, N . \quad M A_{q}\left[\left(\frac{H D}{G D P}\right)_{i, t-p-1}\right]$ denotes a q-quarter moving average of lagged household debt-to-GDP ratio. This indicates that all contemporaneous and lagged parameters may change deterministically with the degree of household indebtedness. We evaluate the impact of monetary policy upon the degree of household debts by comparing impulse response functions measured at the $20^{\text {th }}$ and $80^{\text {th }}$ percentiles of the respective distributions. This approach will help clearly capture how much output and inflation react to monetary policy shocks. In the next step, the interaction term is extended to allow for a vector of dummy variable capturing asymmetries in the transmission of monetary policy across differential monetary policy regimes. The extended interaction term can thus be expressed as: 


$$
\begin{aligned}
A_{i, t-p}= & \alpha_{0, p}+\alpha_{1, p} M A_{4}\left[\left(\frac{H D}{G D P}\right)_{i, t-p-1}\right] \\
& +\alpha_{2, p} D_{i, t}+\alpha_{3, p} D_{i, t} M A_{4}\left[\left(\frac{H D}{G D P}\right)_{i, t-p-1}\right]
\end{aligned}
$$

where $D_{i, t}$ denotes a vector of three indicators, $D_{i, t}=\left[D_{i, t}^{\exp }, D_{i, t}^{c o n}, D_{i, t}^{n e u}\right]$ where $D_{i, t}^{\exp }, D_{i, t}^{c o n}$ and $D_{i, t}^{n e u}$ are the stances of expansionary, contractionary and neutral monetary policy, respectively; and assigns a value of one when it corresponds to the stance, otherwise zero. We then compare the magnitude of transmission between expansionary and contractionary stances. If we confirm the presence of asymmetry in the monetary policy transmission across policy regimes, we can further conduct an additional estimation, accordingly investigating the background behind the regime-dependent impulse responses. We split the sample into the three groups by the predominant type of interest rates, i.e. floating, mixed or fixed types of interest rates that apply to household debts. We then compare the differences in the transmission between floating and fixed types. Indeed, the share of variable-rate loans in total loan outstanding is, if available, a good indicator, considering its time-variant nature. It could, however, be problematic to the extent that it is likely to be endogenous to the phase of business cycle or policy stance. In particular, the predominant interest type shows a little difference across the sample period as we take a look at the trend of the index constructed by the IMF since the 1980s. In this context, we use the time-invariant index since it is robust to endogeneity.

\section{Data}

We use the quarterly data on the unbalanced panel of 28 countries over the period 1984:Q1 2015:Q4.7) Most of the variables used in the analysis

7) We set 1984 as a starting point for the purpose of excluding the effects caused by the Oil crisis. Meanwhile, we note that our result may be severely affected if the post-GFC period is included; many economies maintain their monetary policy at zero lower bounds over considerable periods after the GFC. Thus, we conduct additional estimations covering the pre-GFC period for a robustness check. 
are from the IMF's international financial statistics (IFS), BIS database, and the HAVER database.8) We select the sample countries in terms of data availability, geographical diversity, and the development of financial market, which is a prerequisite for implementing effective monetary policy. The countries comprise Australia, Austria, Belgium, Canada, Czech Republic, Denmark, Finland, France, Germany, Greece, Indonesia, Ireland, Italy, Japan, Korea, Luxembourg, Malaysia, Mexico, Netherlands, New Zealand, Norway, Portugal, Spain, Sweden, Switzerland, Thailand, the United Kingdom, and the United States.9)

In order to evaluate the effectiveness of monetary policy, our baseline econometric specification includes the following variables: real investment $(R I N V)$, real private consumption $(R C O N)$, the current account as a share of GDP $(C A)$, the consumer price index $(C P I)$, the real house prices $(H P)$, the real credit to private non-financial sector (CREDIT), nominal short-term interest rate $(S I R)$, nominal long-term interest rate $(L I R)$, real share prices $(S P)$, and real effective exchange rates (REER). Components of the GDP and the CPI are seasonally adjusted using X-13 ARIMA. For short-term interest rates, we use three-month money market rates, or rates on similar financial instruments. Short-term rates are largely affected by central bank's policy stance. Long-term interest rates, in turn, refer to ten-year government bonds. All the series except interest rates and the current account as a share of GDP are expressed in natural logs. We also use all variables equally, following Christiano et al. (1999) etc.

8) More detailed descriptions of our data set are provided in the Appendix.

9) We acknowledge that individual member countries have not held any authority of independent monetary policy longer since the launch of Eurozone. Nevertheless, we include the Eurozone member countries in the sample for several following reasons: 1) our study focuses on the effect in direction from monetary policy shocks to real economy, 2) excluding the Eurozone member countries would limit the number of the sample for panel analysis of transmission of monetary policy, and 3) the economic indicators of the sample countries, such as Germany, France, Italy, Spain etc. have sterling impacts on the ECB's decision on key rates, given their dominant positions in the Eurozone economy. Moreover, we note that the recent literature, e.g. Jannsen et al. (2015), Sa et al. (2013) etc., also includes Eurozone member countries. 
Table 1. Data Sources and Description

\begin{tabular}{cccccc} 
Variable & Mean & Std. Dev. & Min & Max & Sources \\
\hline Short-term Interest & 7.02 & 8.23 & -0.80 & 45.2 & IMF IFS \\
Long-term Interest & 7.37 & 4.81 & -0.21 & 42.6 & IMF IFS \\
Log(RGDP) & 12.97 & 2.64 & 8.64 & 21.55 & IMF IFS \\
Log(RCON) & 12.16 & 2.49 & 7.68 & 20.96 & IMF IFS \\
Log(RINV) & 11.54 & 2.87 & 6.56 & 20.43 & IMF IFS \\
CA & 2.00 & 6.84 & -20.33 & 40.04 & IMF IFS \\
Log(CPI) & 4.14 & 0.79 & -3.41 & 4.81 & IMF IFS \\
Log(RSHARE) & 5.50 & 1.76 & 1.76 & 10.60 & Haver \\
Log(REER) & 4.60 & 0.15 & 3.69 & 5.22 & BIS database \\
Log(CREDIT) & 10.16 & 3.61 & 3.60 & 21.82 & BIS database \\
Log(RHP) & 4.91 & 0.72 & -2.41 & 6.09 & BIS, Haver \\
HD Ratio & 54.59 & 27.12 & 4.13 & 139.5 & BIS database \\
\hline
\end{tabular}

Notes: Short-term interest rates are three-month nominal money market rates or the rates on similar financial instruments. Long-term interest rates are the nominal yields on ten-year government bonds. Components of GDP and CPI are seasonally adjusted using X-13 ARIMA.

For interaction terms, we adopt the two variables: the household indebtedness as a share of GDP; and the indicators of central bank's monetary policy stance. We first need to define a state of high household indebtedness. In order to control for the effect of economic growth, financial deepening and demographic factor, we detrend the household debt-to-GDP ratio using the HP filter with a smoothing parameter, $\lambda=10,000$ and construct cyclical debt gap ratios, following Drehmann and Tsatsaronis (2014), Bernadini and Peersman (2015), and Alpanda and Zubairy (2016). The variable also enters the regression in the form of a previous four-quarter moving average to address potential problems arising from endogeneity. Figure 1 shows that the detrended debt ratio is close to normal distribution, concentrating around 0 , while debt ratios are widely scattered ranging from $5 \%$ to $140 \% .10$ )

10) We, conducting the estimation with the household debt-to-GDP ratio not detrended, obtain the results which are consistent with those of baseline estimations. The estimation results will be provided upon request. 

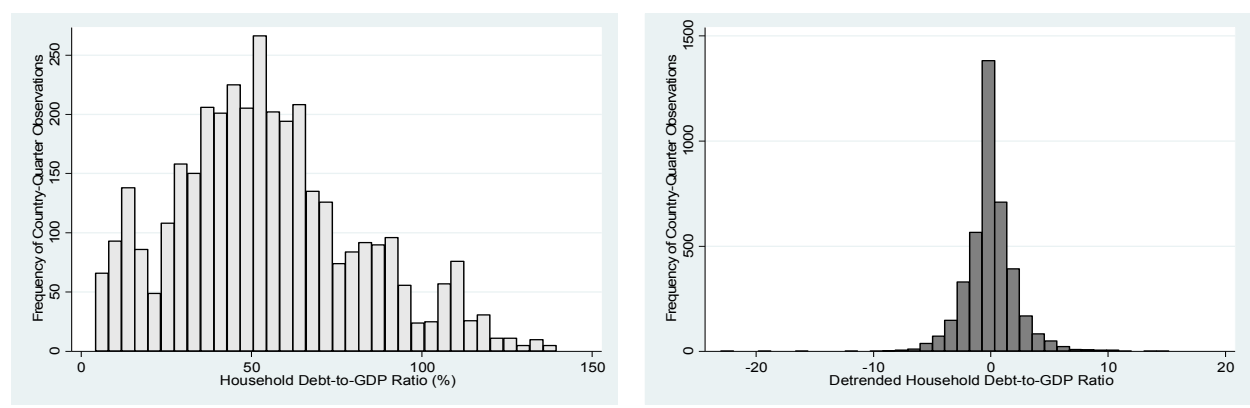

In addition, we identify the stance of monetary policy, and then decompose the sample into the three phases: the periods of expansionary, contractionary and neutral monetary policy stances. Our approach to obtain the policy stance is very simple. Specifically, to measure the policy stance, we apply a VAR-based approach, allowing for policy rates or overnight rates as an indicator of policy stance, which is in the spirit of Bernanke and Blinder (1992). For non-policy variables, we utilize GDP and consumer prices in log. We then assume that non-policy variables, such as GDP and prices, are not contemporaneously affected by policy shocks. Once the VAR is estimated, a Choleski decomposition generates an estimated series for an exogenous monetary policy shock.11)12) In order to consider a respective policy stance, we construct a vector of three indicators, $D_{i, t}=\left[D_{i, t}^{\exp }, D_{i, t}^{c o n}, D_{i, t}^{n e u}\right]$ and assign a value of one when it corresponds to the stance, otherwise zero.

Lastly, the predominant type of interest rate is constructed using the IMF data by Cerutti et al. (2015). 15 economies manage variable types of interest rates predominantly while the fixed rate type of loans is

11) Following Bernanke and Mihov (1998) and Fung and Yuan (2001), we construct a monetary policy stance measure by subtracting its 6-quarter moving average from the identified policy shock. We then assign contractionary stance $D_{i, t}^{c o n}$ to the upper 40 percentile; expansionary stance $D_{i, t}^{\exp }$ to the lower 40 percentile; and neutral stance to $D_{i, t}^{n e u} 20$ percentile around the median.

12) We use each country's policy rate as a policy variable to identify the monetary policy stance. For the period before the introduction of interest rate-targeting mechanism, we instead utilize short-term rates with maturities of less-than three months, such as overnight rates. 


\section{Table 2. Predominant Type of Interest Rate Contracts}

\begin{tabular}{c|c|c|c}
$\begin{array}{c}\text { Interest } \\
\text { Type }\end{array}$ & Variable & Mixed & Fixed \\
\hline \multirow{2}{*}{ Country } & $\begin{array}{c}\text { Australia, Finland, Greece, } \\
\text { Indonesia, Italy, Luxembourg, } \\
\text { Malaysia, Mexico, New Zealand, } \\
\text { Norway, Portugal, South Korea, } \\
\text { Spain, Sweden, UK }\end{array}$ & $\begin{array}{c}\text { Canada, Denmark, Ireland, } \\
\text { Israel, Japan, Thailand }\end{array}$ & $\begin{array}{c}\text { Austria, Belgium, France, } \\
\text { Germany, Netherlands, } \\
\text { Switzerland, US }\end{array}$ \\
\hline
\end{tabular}

Source: Cerutti et al. (2015)

predominant in 7 countries. In comparison with irregular previous reports on the similar topics, we find that there have been few differences in the interest type of respective countries over time since the 1980s.

\section{Estimation and Inference}

Our estimation employs a Bayesian methodology, building on Sá et al. (2014). We first estimate the recursive form of an interacted PVAR model, using the Ordinary Least Squares. Two lags are chosen in the baseline specification by the Akaike information criterion. ${ }^{13)}$ We update the estimates with prior information, utilizing an uninformative Normal-Wishart prior. We draw all recursive-form parameters from the posterior, using Monte Carlo integration methods (Uhlig, 2005 and Koop and Korobilis, 2010). As in Cogley and Sargent (2005) and Sá et al. (2014), we also discard explosive draws according to prior conditions of non-explosive responses.

For the identification of monetary policy shocks, we employ the sign restriction approach proposed by Canova and De Nicoló (2002), Uhlig (2005) etc. This approach has several advantages over the alternatives. First, it has been widely used to address challenges in analyzing the effect of monetary policy, such as price puzzle, exchange rate puzzle etc. Impulse

13) Similar previous literature by Sá et al. (2014) and Jannsen et al. (2015) also choose two quarter lags. 
responses are also independent of the ordering of endogenous variables. The signs of impulse responses are, instead, determined in line with economic theory. Specifically, we follow the identification restrictions on monetary policy shocks, well documented by Christiano et al. (1999). In our estimation, we impose the restrictions in response to a restrictive monetary policy shock, short-term interest rate and real effective exchange rate rise during the first to fourth quarters; and prices decrease from the second to fourth quarter while remaining agnostic with respect to GDP and other variables.

That being said, the behaviors of economic variables may diverge from the theory in highly inflationary pressure or extremely recessionary periods. For a robustness check, we therefore conduct the estimation excluding the post-GFC period.

In practice, we proceed in the following steps. We take a random draw from the posterior of reduced-form parameters and compute the lower-triangular Cholesky decomposition. We then consider 500 random draws of the rotation matrix and compute the set of implied structural impulse responses for each regime. If the draw satisfies sign restrictions, we store the value, otherwise discard it. We reiterate this process 500 times, and thereby compute the $16^{\text {th }}$ and $84^{\text {th }}$ percentile of confidence bands as well as the median.

\section{Results}

In this section, we report the results of impulse response functions on the transmission of monetary shocks. We then conduct several robustness checks based on the identification of interaction terms as well as the resampling of the period. 


\section{Monetary Policy Transmission}

Figure 1, first, displays the results of the baseline estimation that is not augmented with any interaction term in equation (1). The solid red line represents the median impulse response and the shaded red areas are the $16^{\text {th }}$ and $84^{\text {th }}$ percentiles of the respective posterior distribution. The gray shaded area indicates variables and the horizon where sign restrictions are imposed.

We observe falls in financial variables and resulting decreases in consumption, investment and prices, following a one-standard deviation contractionary adjustment to monetary policy. Specifically, in response to a contractionary monetary policy shock, we see contemporaneous drops in the prices of short and long-term bonds, share prices, and house prices. Similarly, the reaction of credit to the non-financial private sector is negative on the impact, and returns to origin gradually after bottoming out at around 10th quarter. In the case of real economy, the responses of demand variables appear to be negative and persistent over considerable horizons. Consumption reaches bottom at around 0.2 percent five quarters after the impact, and rebounds very gradually over time. Investment declines on impact by about 0.5 percent and then hovers at a similar level until the fifth quarter. By contrast, current account turns to deficits after temporary improvement in the impact, which supports the presence of so called "J-curve effect". 
Figure 1. Baseline Impulse Responses to a Monetary Policy Shock
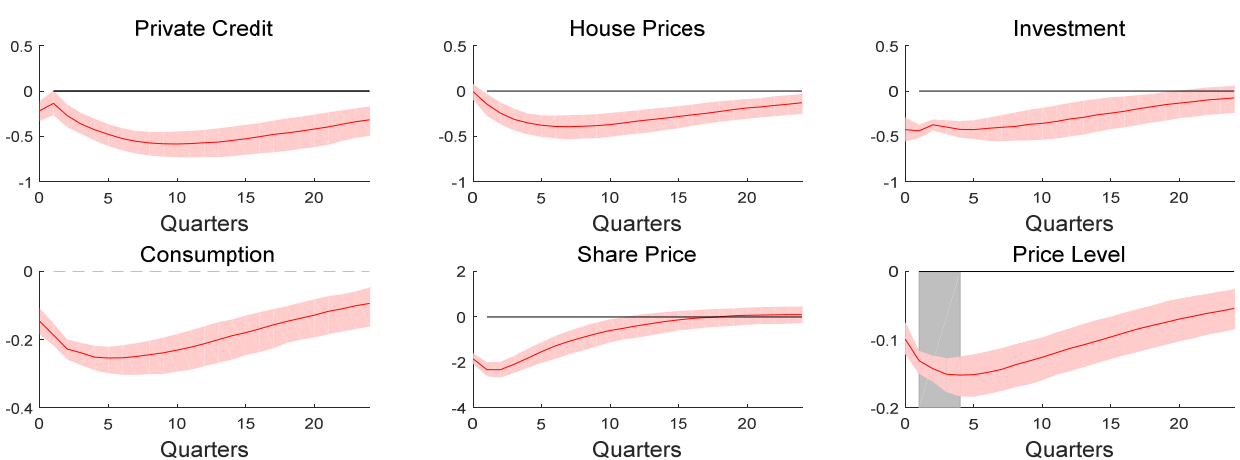

Price Level
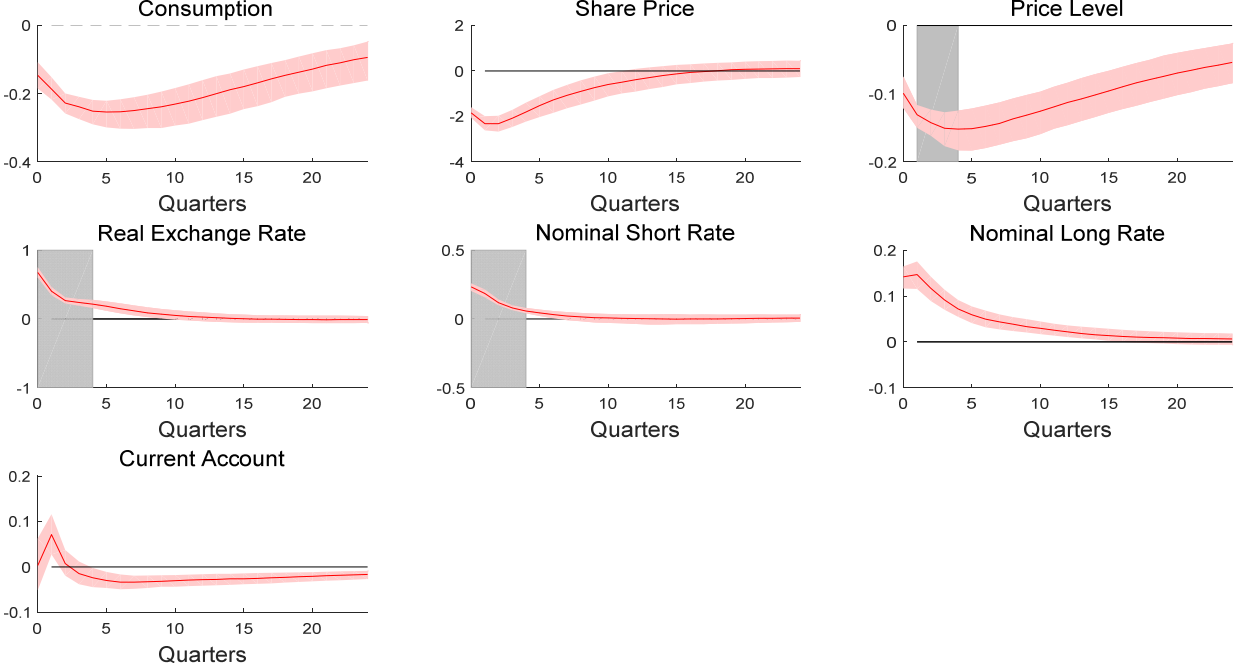

Notes: The gray shaded area depicts the variables and the horizon on which sign restrictions are imposed. The standard error bands which account for parameter uncertainty are the 16th and 84th percentiles of the set of accepted impulse response functions for all draws.

We now proceed to present the differences in the transmission of a monetary shock by the degree of household indebtedness. Figure 2 displays the impulse responses of each variable of interest to a contractionary monetary shock. We note that the responses of investment and consumption are significantly larger with high debts. In particular, the difference in the response of consumption is remarkably huge from the impact. We also find significantly larger deficits in the high debt state. In contrast, there appears to be no significant difference in the response of prices. This finding provides support for the notion that the impact of a monetary policy shock should be sizeable in the high debt state. 
Figure 2. Differences in Impulse Responses to a Monetary Policy Shock by the Degree of Household Indebtedness
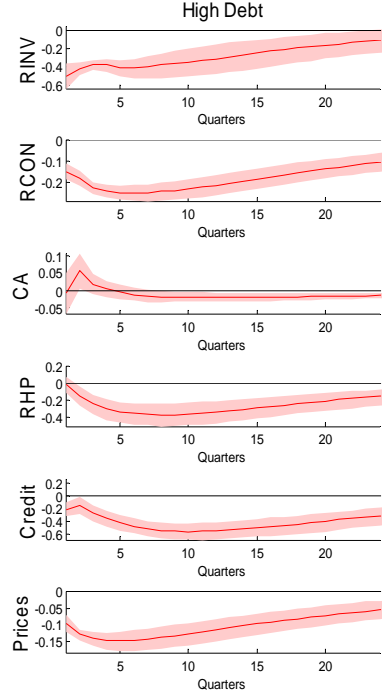
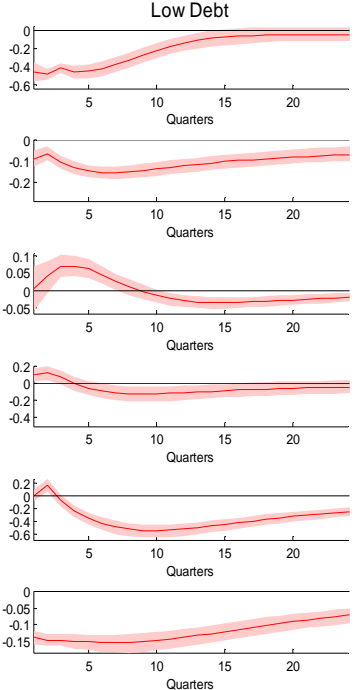
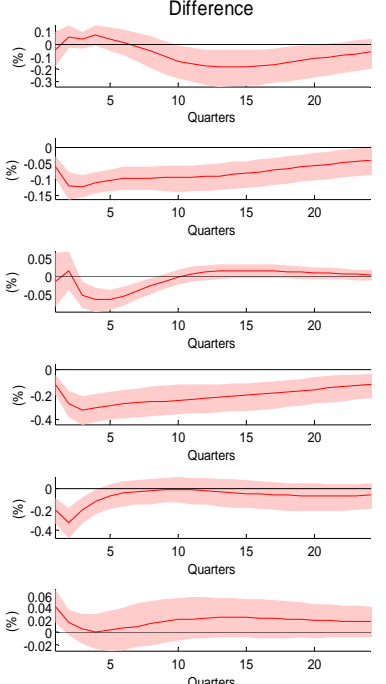

Notes: The gray shaded area depicts the variables and the horizon on which sign restrictions are imposed. The standard error bands which account for parameter uncertainty are the 16th and 84th percentiles of the set of accepted impulse response functions for all draws. We report impulse responses evaluated at $80 \%$ and $20 \%$ of the gap ratios of the household indebtedness.

Furthermore, we delve into the backdrop behind larger responses in the high debt state. We first augment the baseline debt-dependent estimation model with the interaction term of monetary policy stance in order to investigate if there is an asymmetry of the responses by the monetary policy regime. Estimation results presented in Figure 3 show that the impulse responses of consumption, investment and current account are significantly larger in a contractionary monetary policy stance. In particular, the responses of consumption and current account becomes significantly larger $5 \sim 6$ quarters after the impact in the contractionary stance, and the differences last considerably long horizons.

In contrast, Figure 4, which reports the responses with low debts, does not exhibit significant heterogeneity in the responses by monetary policy stances. Although there is a little difference in the response of consumption after 15 quarters, we can assert that the difference is trivial given a 
Figure 3. Differences in Impulse Responses to a Monetary Policy Shock by Monetary Policy Stance at the High Degree of Household Indebtedness

High Debt-Contraction
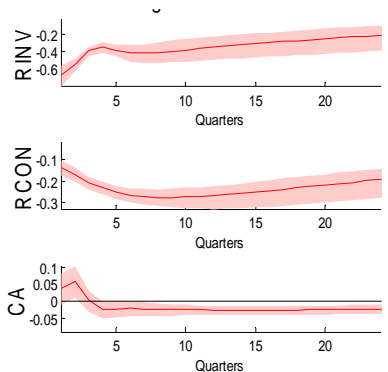

$\underset{-0.6}{\stackrel{0}{T_{0}} \cdot 0.2}$
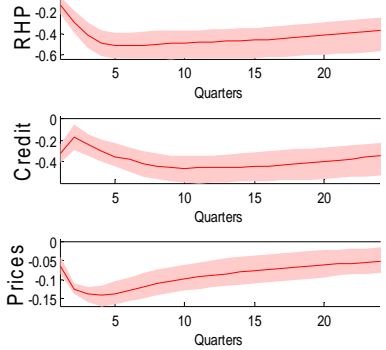

High Debt-Expansion
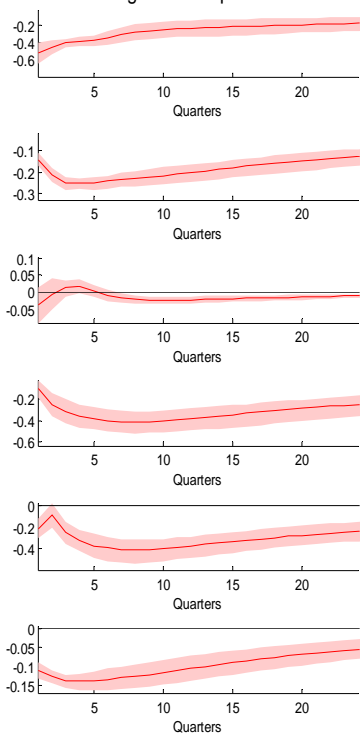

Difference
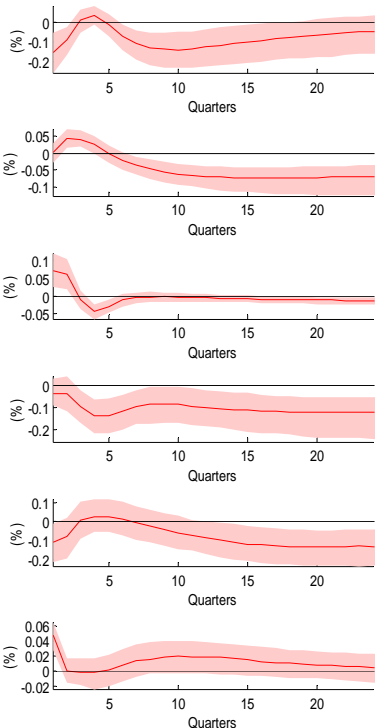

Notes: To facilitate the comparison between the two regimes, we present the impulse responses to a contractionary shock in an expansionary monetary policy stance as well. The gray shaded area depicts the variables and the horizon on which sign restrictions are imposed. The standard error bands which account for parameter uncertainty are the 16th and 84th percentiles of the set of accepted impulse response functions for all draws.

stronger response in the expansionary stance at the early stage of the impact. Our findings appear to lend support for the supposition that larger responses with high debts arise from the "cash flow channel" of a contractionary monetary shock in the high debt state. In contrast, we do not find any significant difference in the response of prices, which is broadly in line with existing literature, such as Weisse (1999), Garcia and Schaller (2002) and Lo and Piger (2005).

Lastly, we test for the supposition that the effect of a monetary shock on 
Figure 4. Differences in Impulse Responses to a Monetary Policy Shock by Monetary Policy Stance at the Low Degree of Household Indebtedness
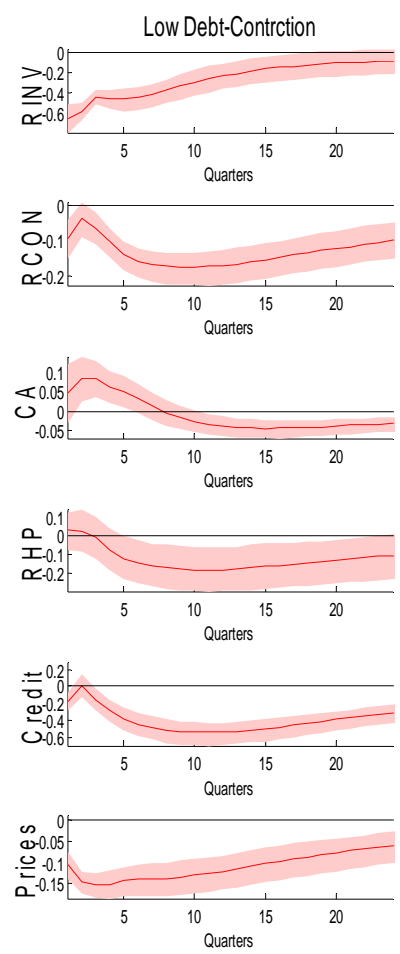
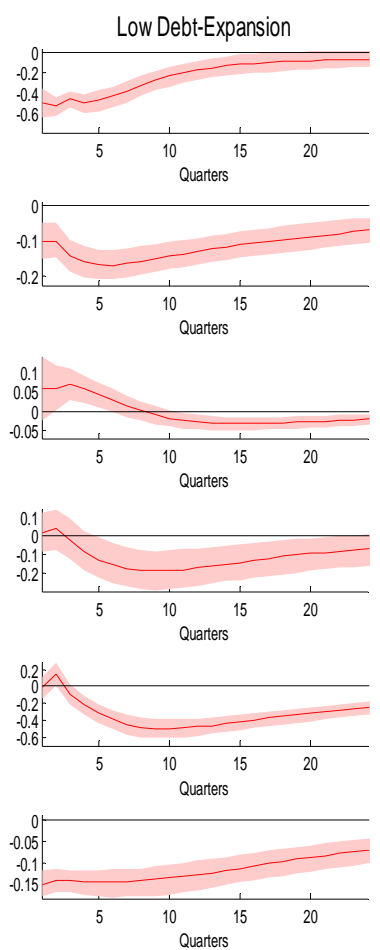
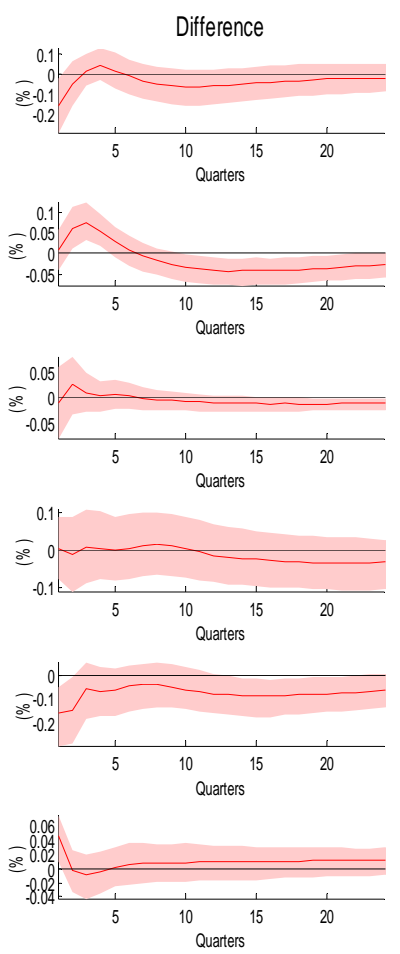

Notes: To facilitate the comparison between the two regimes, we present the impulse responses to a contractionary shock in an expansionary monetary policy stance as well. The gray shaded area depicts the variables and the horizon on which sign restrictions are imposed. The standard error bands which account for parameter uncertainty are the 16th and 84th percentiles of the set of accepted impulse response functions for all draws.

the economy largely depends on the predominant type of interest rate that applies to household debts. Specifically, we implement additional estimations, splitting the sample into the three groups by the predominant types of interest rate: fixed, mixed, adjustable rate. Figure 5 compares the results across the economies who manage adjustable and fixed rate loans predominantly. The results indicate that the higher the share of the 
Figure 5. Differences in Impulse Responses to a Monetary Policy Shock

by Predominant Interest Type at the High Household Debt and a Contractionary Monetary Policy Stance
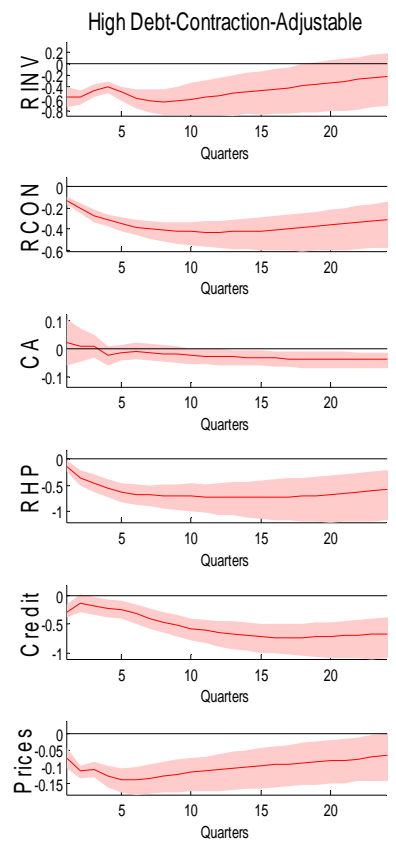
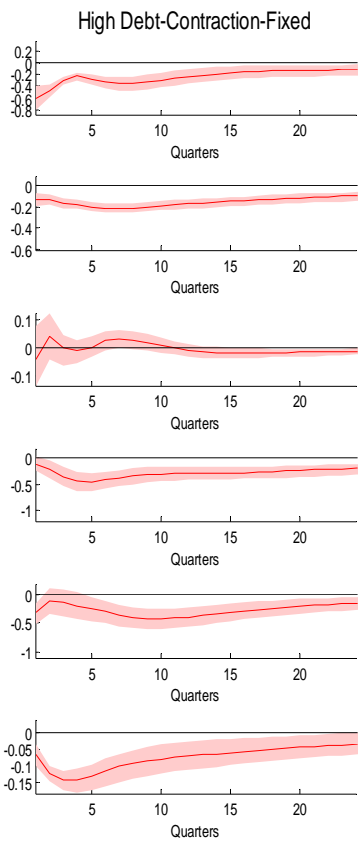

Difference
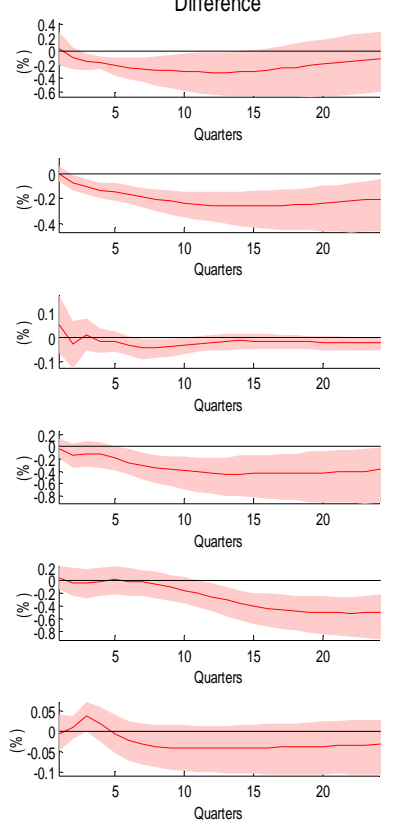

Notes: The gray shaded area depicts the variables and the horizon on which sign restrictions are imposed. The standard error bands which account for parameter uncertainty are the 16th and 84th percentiles of the set of accepted impulse response functions for all draws.

adjustable-rate loans is, the greater impact a contractionary monetary shock has on the real economy. In particular, it seems that growing and persistent divergence in the responses of consumption and investment arises from the fact that adjustable-rate loans comprise the loan contract whose rates can be readjusted after the delay of one or three years.

\section{Robustness Check}

In this section, we take into account several robustness checks on our baseline estimation. We are intended to confirm that the results of our baseline estimation are robust to the definitions of the interaction term variable, sample periods and endogenous variables. 
Figure 6. Differences in Impulse Responses to a Monetary Policy Shock by the Degree of Household Indebtedness
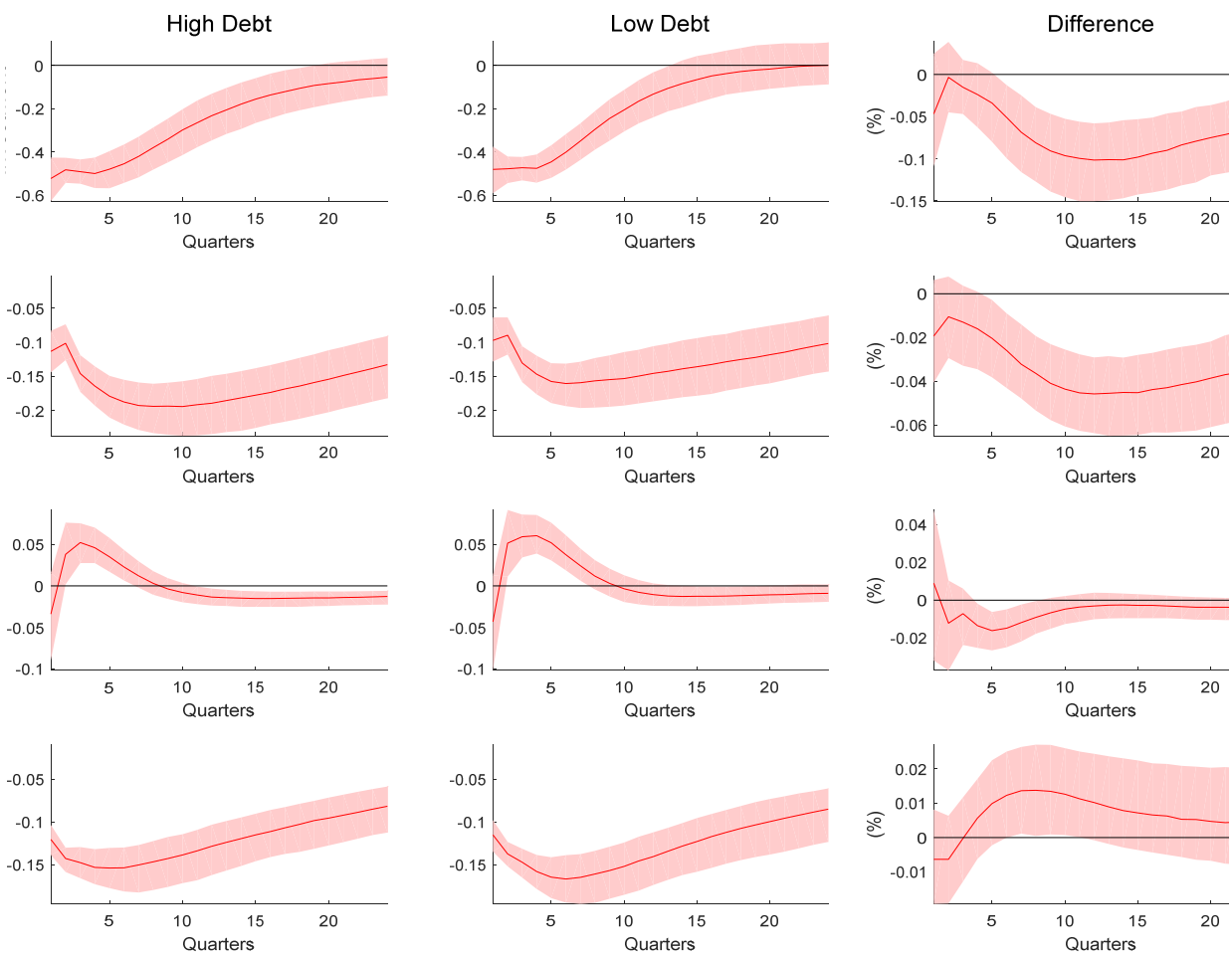

Notes: For the interaction term of the degree of household debt, we use a log-linearized household debt, which is detrended by the HP filter with $\lambda=10^{4}$. The gray shaded area depicts the variables and the horizon on which sign restrictions are imposed. The standard error bands which account for parameter uncertainty are the 16th and 84th percentiles of the set of accepted impulse response functions for all draws. We report impulse responses evaluated at $80 \%$ and $20 \%$ of the gap ratios of household indebtedness.

\subsection{Alternative I nteraction-term Variable}

In our baseline estimation, we employ a detrended household debt-to-GDP ratio, using the HP filter with smoothing parameter of $10^{4}$ as our interaction term variable. In order to check the robustness of baseline specification, we substitute the log-linearized household debt detrended in the same manner above for the ratio. 
As a result, we obtain similar results to those of the baseline estimation. Figure 6 displays the impulse response to a contractionary monetary shock by the degree of household debt. Instead, differences in the responses of investment and consumption are of, if anything, a smaller magnitude than that of the baseline estimation. The response of investment is larger by 0.1 percent point with high debts than with low debts in this definition while being larger by around 0.2 percent point in the baseline identification. The difference in the response of consumption is as small as 0.04 percent point, compared to approximately 0.1 percent point in the baseline identification. Nevertheless, we note that the differences are still statistically significant and persistent.

With high debts, the responses of investment and consumption turn out to be larger in a contractionary monetary stance than in an expansionary stance. Moreover, the differences in the responses of consumption and investment are of the similar magnitude to those of the baseline model. As noted above, the difference in consumption response becomes larger over time, which is supposed to arise from the staggered adjustment of variable interest rates. Meanwhile, in contrast to the result of the baseline estimation, the current account does not show a significant difference between the two regimes, although still exhibiting the J-curve effect. The prices display a homogeneous behavior, bottoming out at -0.15 percent and returning to a trend moderately. 
Figure 7. Differences in Impulse Responses to a Monetary Policy Shock by Monetary Policy Stance at the High Degree of

\section{Household Indebtedness}
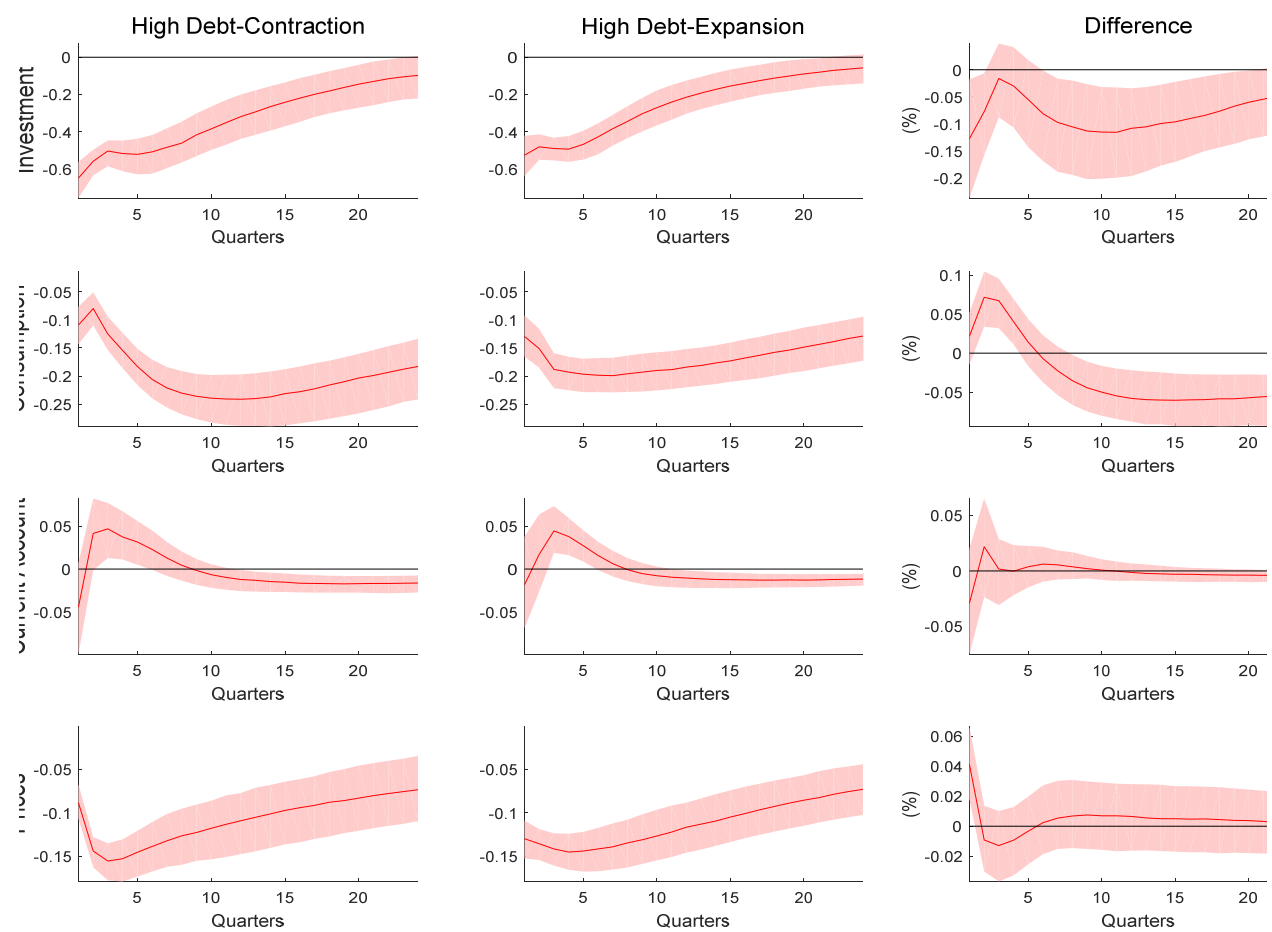

Notes: For interaction term of the degree of household debt, we use a log-linearized household debt, which is detrended by the HP filter with $\lambda=10^{4}$. To facilitate the comparison between the two regimes, we present the impulse responses to contractionary shock in an expansionary monetary policy stance as well. The gray shaded area depicts the variables and the horizon on which sign restrictions are imposed. The standard error bands which account for parameter uncertainty are the 16th and 84th percentiles of the set of accepted impulse response functions for all draws.

Finally, augmentation with additional interaction terms, predominant type of interest also gives us similar results as shown in Figure 8. One difference is that the gap in prices is not zero, indicating that prices significantly respond to a monetary shock. Although it is difficult to find a potential culprit for this divergence, we need to further check if the difference may be applied to prices in a more elaborate manner. 
Figure 8. Differences in Impulse Responses to a Monetary Policy Shock

by Predominant Interest Type at the High Degree of Household Indebtedness and a Contractionary Monetary Policy Stance
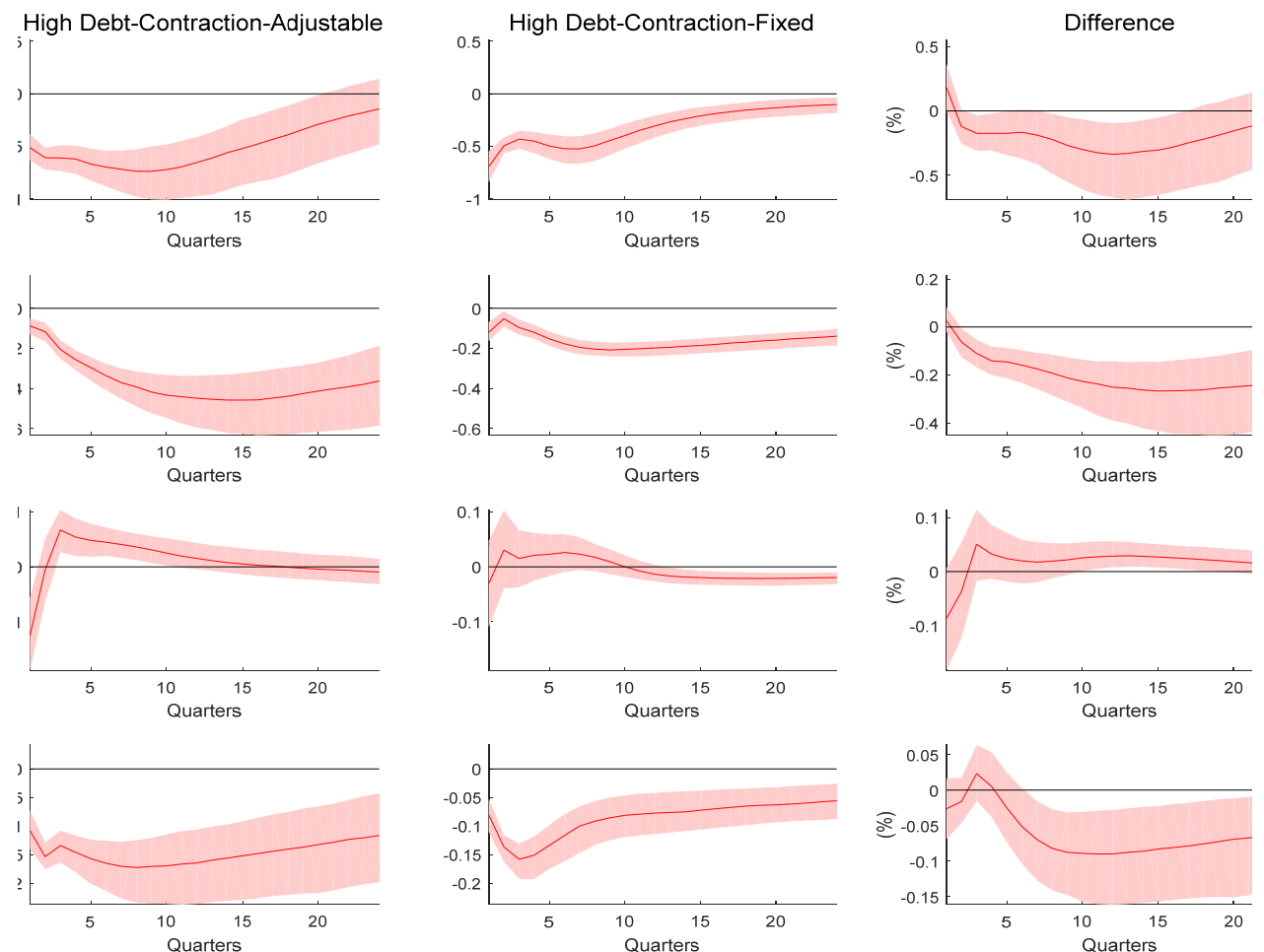

Notes: For the interaction term of the degree of household debt, we use a log-linearized household debt which is detrended by the HP filter with $\lambda=10^{4}$. The gray shaded area depicts the variables and the horizon on which sign restrictions are imposed. The standard error bands which account for parameter uncertainty are the 16th and 84th percentiles of the set of accepted impulse response functions for all draws.

\subsection{Exduding post-GFC period}

As mentioned above, the identification by sign restrictions may face the concern that, in highly inflationary or deflationary periods, the restrictions broadly supported by economic intuitions and theories may fail to fit the data well (Fry and Pagan, 2011). We therefore resample our data excluding the post-GFC period.

As a result, we find that the differences between the states become 
Figure 9. Differences in Impulse Responses to a Monetary Policy Shock by the Degree of Household Indebtedness
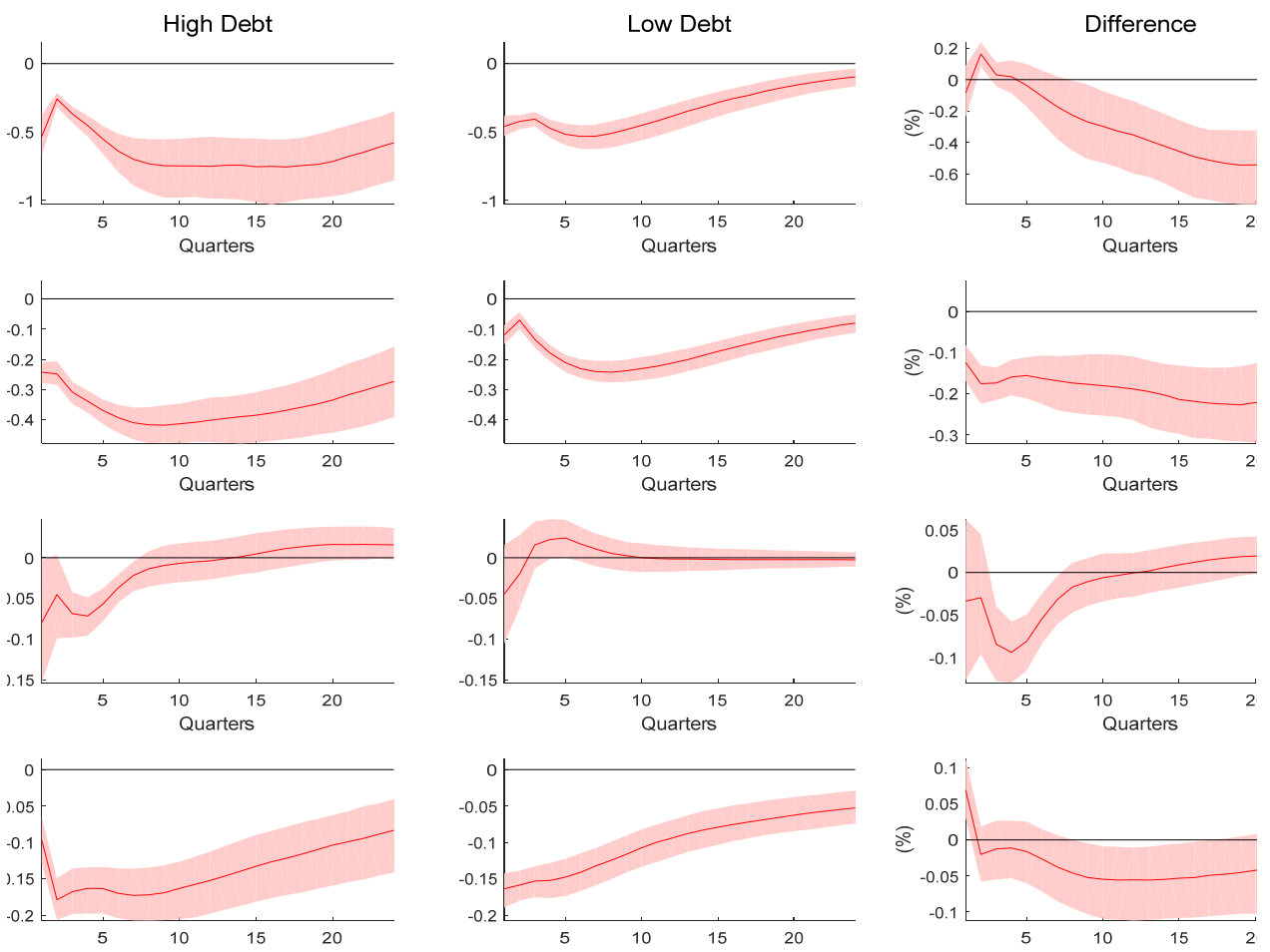

Notes: This sample covers the pre-GFC period ranging from 1984Q1 to 2007Q4. The gray shaded area depicts the variables and the horizon on which sign restrictions are imposed. The standard error bands which account for parameter uncertainty are the 16th and 84th percentiles of the set of accepted impulse response functions for all draws. We report impulse responses evaluated at $80 \%$ and $20 \%$ of the gap ratios of household indebtedness.

larger, compared to the baseline estimation. Figure 9 to Figure 11 indicate exhibit consistently and markedly stronger responses in terms of consumption and investment. We thus believe that this finding provides a stronger support for our notion. 
Figure 10. Differences in Impulse Responses to a Monetary Policy Shock by Monetary Policy Stance at the High Degree of

Household Indebtedness
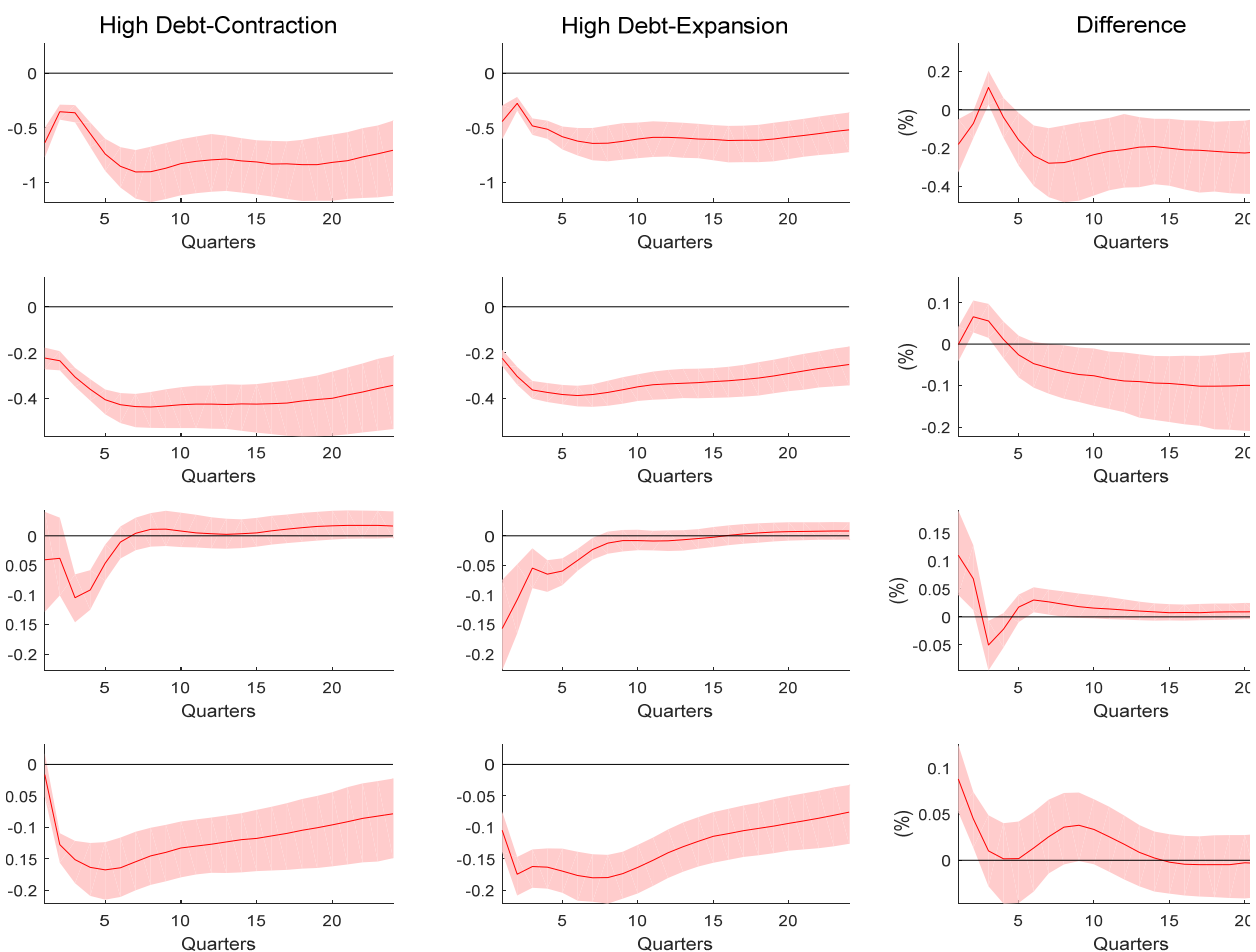

Notes: This sample covers the pre-GFC period ranging from 1984Q1 to 2007Q4. The gray shaded area depicts the variables and the horizon on which sign restrictions are imposed. The standard error bands which account for parameter uncertainty are the 16th and 84th percentiles of the set of accepted impulse response functions for all draws. 
Figure 11. Differences in Impulse Responses to a Monetary Policy Shock

by Predominant Interest Type at the High Degree of Household Indebtedness and a Contractionary Monetary Policy Stance
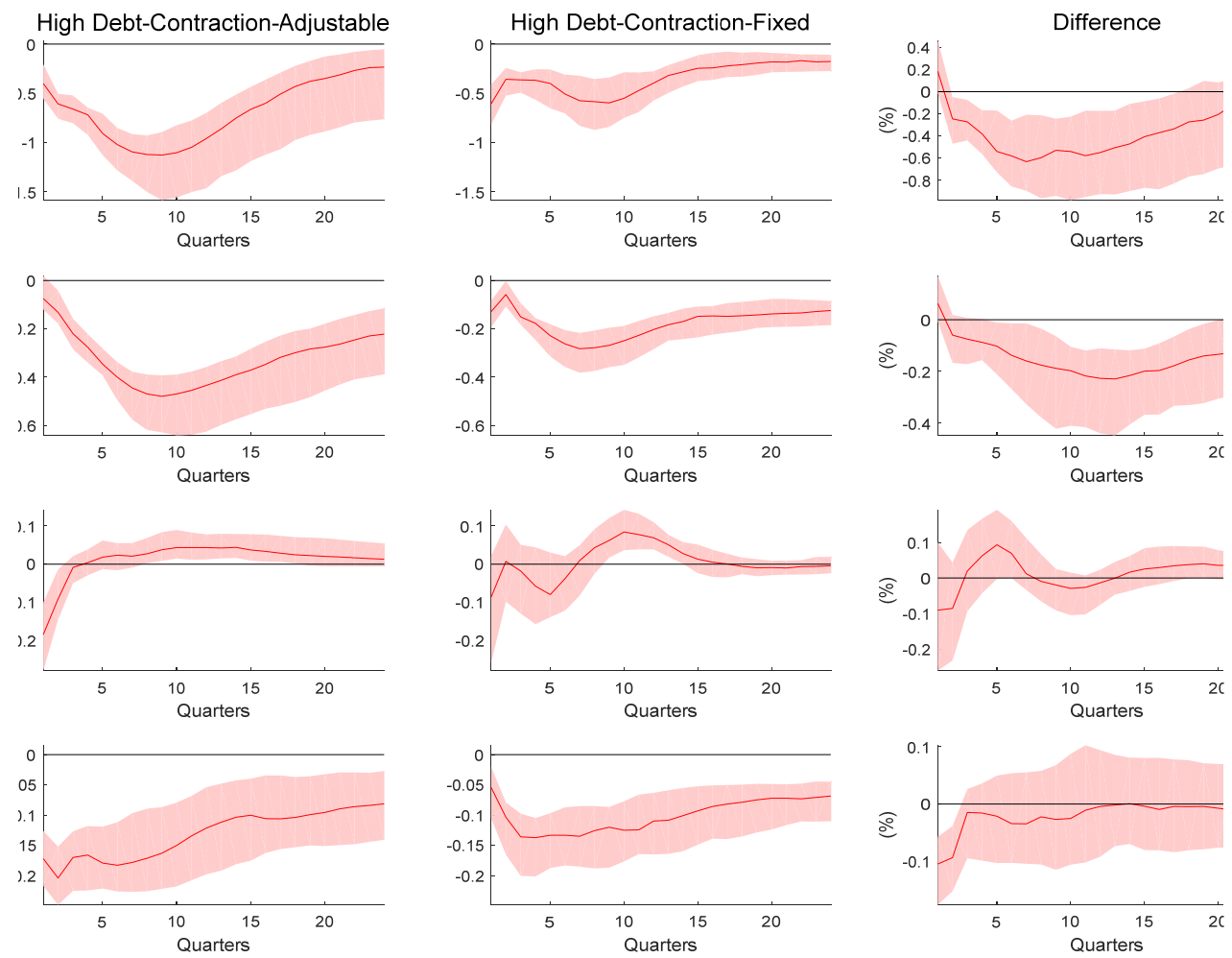

Notes: This sample covers the pre-GFC period ranging from 1984Q1 to 2007Q4. The gray shaded area depicts the variables and the horizon on which sign restrictions are imposed. The standard error bands which account for parameter uncertainty are the 16th and 84th percentiles of the set of accepted impulse response functions for all draws.

\subsection{Substituting GDP for I ts Component}

Now, we examine whether our results are affected by the substitution of aggregate GDP for the components of GDP in our baseline model. Figure 12 shows the impulse response of GDP to a contractionary monetary shock by the degree of debt. We observe that GDP falls by 0.5 percent six quarters after the impact in the high debt state while by around 0.3 
Figure 12. Differences in Impulse Responses to a Monetary Policy Shock by the Degree of Household Indebtedness
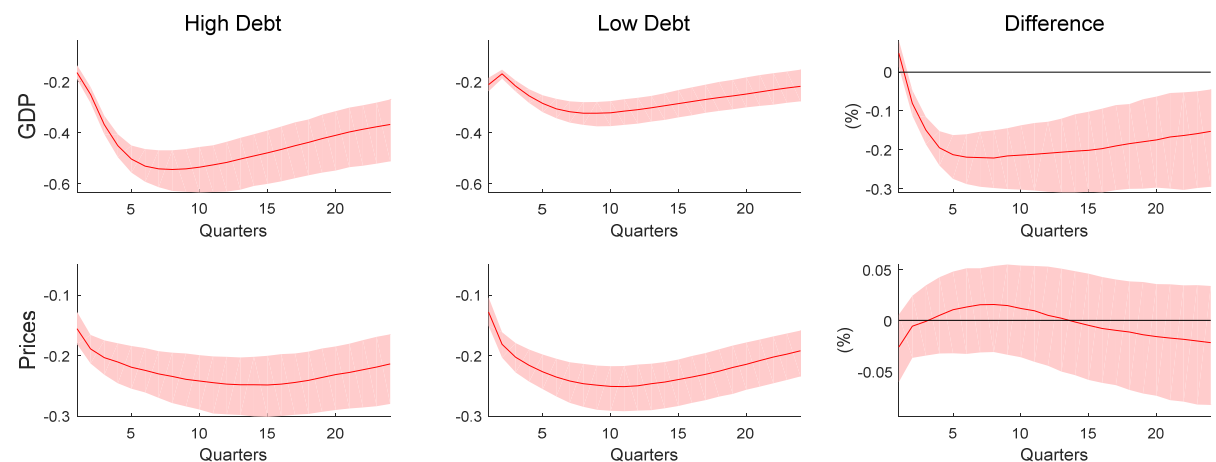

Notes: The gray shaded area depicts the variables and the horizon for which sign restrictions are imposed. The standard error bands which account for parameter uncertainty are the 16th and 84th percentiles of the set of accepted impulse response functions for all draws. We report impulse responses evaluated at $80 \%$ and $20 \%$ of gap ratios of the household indebtedness.

percent in the low debt state. The impact on prices does not diverge across the states. These observations are broadly consistent with our estimation results above.

We also obtain the same result when we check for asymmetry across the monetary policy regimes, as shown in Figure 13. Instead, we observe that the impact on prices is stronger in an expansionary monetary policy stance than in a contractionary stance, which is a conflicting result to previous ones. We therefore find that the difference in the impact on prices needs to be interpreted with caution. Nevertheless, we find our results to remain unchanged.

Finally, Figure 14 indicates that contractionary monetary shocks exert a greater impact on GDP in the economies with a higher share of adjustable rate loans in the state of high debt. This result is also consistent with the findings above. 
Figure 13. Differences in Impulse Responses to a Monetary Policy Shock by Monetary Policy Stance at the High Degree of Household Indebtedness
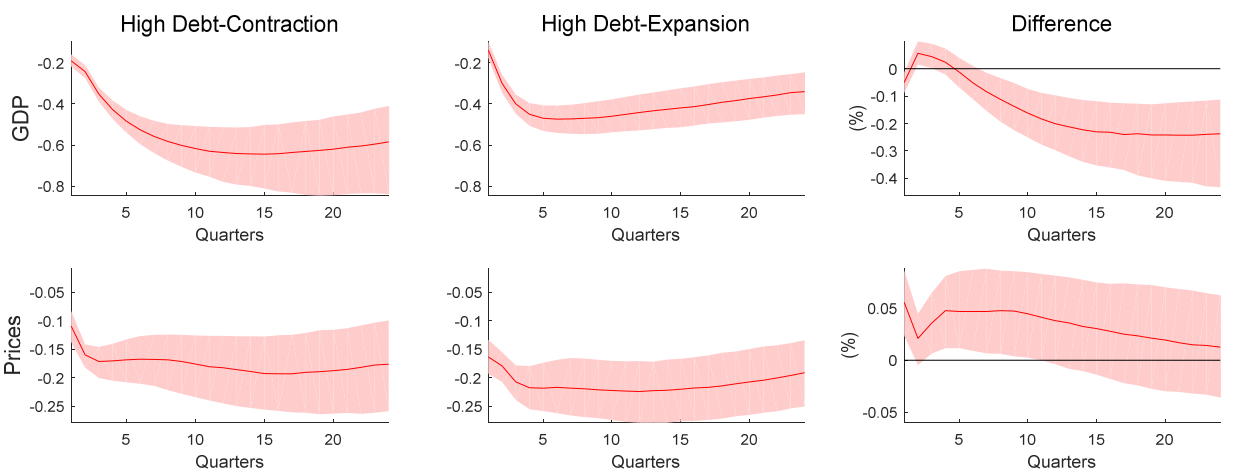

Notes: The gray shaded area depicts the variables and the horizon on which sign restrictions are imposed. The standard error bands which account for parameter uncertainty are the 16th and 84th percentiles of the set of accepted impulse response functions for all draws.

Figure 14. Differences in Impulse Responses to a Monetary Policy Shock

by Predominant Interest Type at the High Degree of Household Indebtedness and a Contractionary Monetary Policy Stance
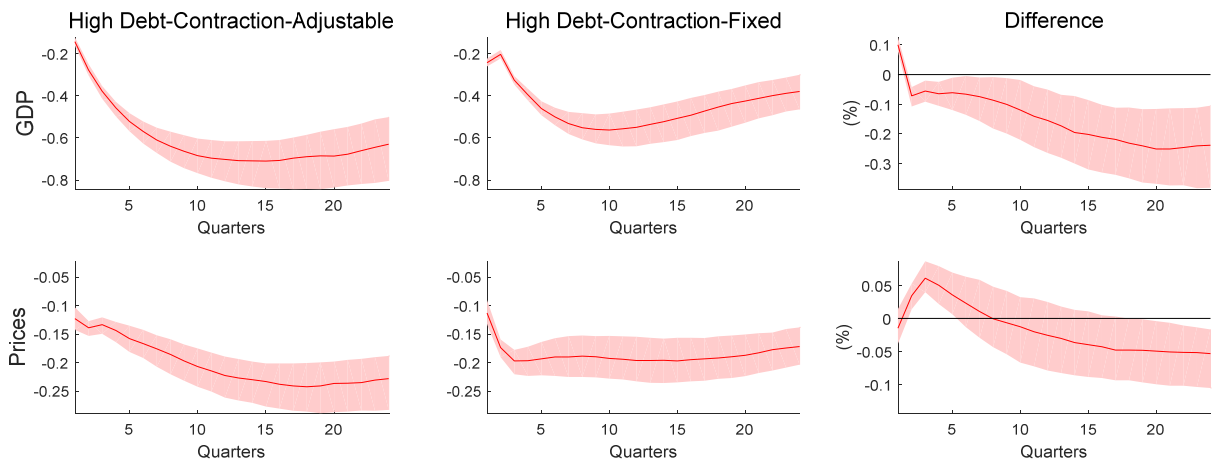

Notes: The gray shaded area depicts the variables and the horizon on which sign restrictions are imposed. The standard error bands which account for parameter uncertainty are the 16th and 84th percentiles of the set of accepted impulse response functions for all draws. 


\subsection{Adding Some Variables Capturing Global Economic Adivities}

To strengthen our identification of monetary shocks, we add more endogenous variables that can help capture the factors affected by the global economy. For this purpose, we construct the global GDP and the global CPI index, using the data available in the IFS database. We then add these variables to the top of the vector of endogenous variables in the baseline estimation model. Figure 15 suggests that the response of consumption to monetary shocks is much larger in the high debt state while that of prices is not significantly different between the two states, which is in line with the baseline estimation. Figure 16 is also consistent with the baseline estimation in that contractionary monetary shocks have a stronger transmission effect on the real sector than expansionary shocks. In contrast, the responses Figure 17, which displays the difference in the response when splitting the sample according to the predominant type of interest rate, exhibit a bit different result from the baseline estimation. Specifically, the difference in the effect of contractionary monetary shocks on investment becomes insignificant although the effect is still stronger in a group with a higher share of adjustable rate loans on average. Moreover, the response of prices turns out to be larger in countries that predominantly have fixed rate loans, which is different from the baseline estimation. 
Figure 15. Differences in Impulse Responses to a Monetary Policy Shock by the Degree of Household Indebtedness
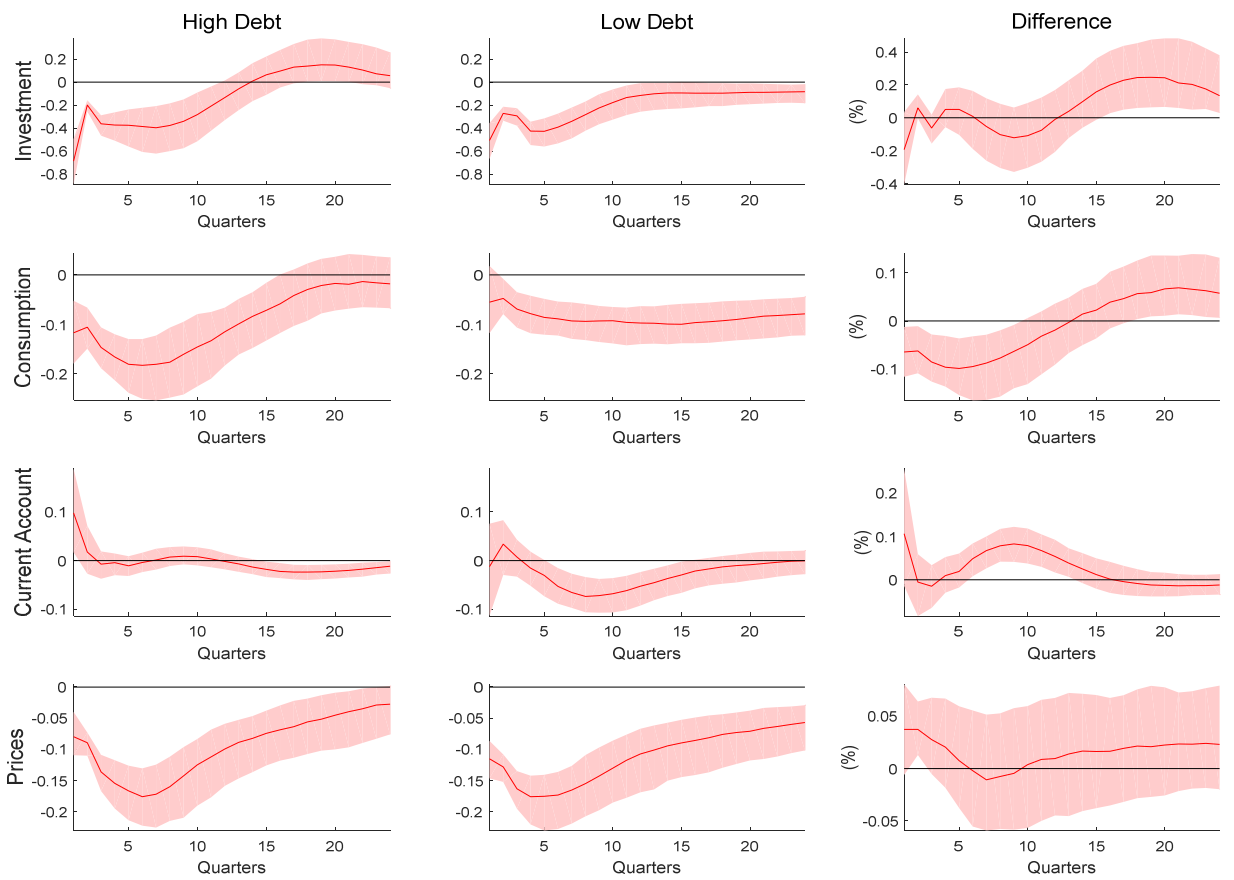

Notes: The gray shaded area depicts the variables and the horizon on which sign restrictions are imposed. The standard error bands which account for parameter uncertainty are the 16th and 84th percentiles of the set of accepted impulse response functions for all draws. We report impulse responses evaluated at $80 \%$ and $20 \%$ of gap ratios of the household indebtedness. 
Figure 16. Differences in Impulse Responses to a Monetary Policy Shock by Monetary Policy Stance at the High Degree of Household Indebtedness
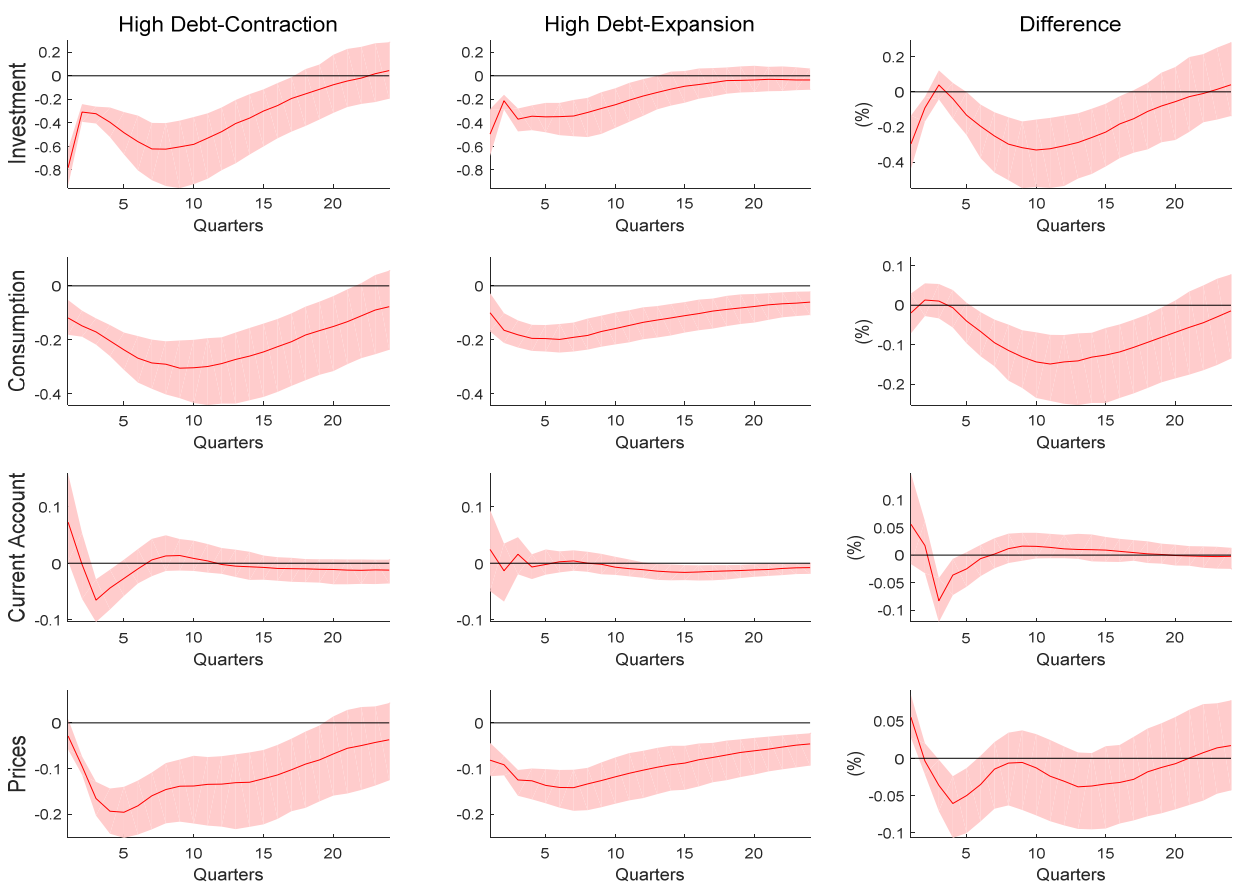

Notes: To facilitate comparison between two regimes, we present the impulse responses to contractionary shock in expansionary monetary policy stance as well. The gray shaded area depicts the variables and the horizon on which sign restrictions are imposed. The standard error bands which account for parameter uncertainty are the 16th and 84th percentiles of the set of accepted impulse response functions for all draws. 
Figure 17. Differences in Impulse Responses to a Monetary Policy Shock by Predominant Interest Type with High Household Debts at a Contractionary Monetary Policy Stance
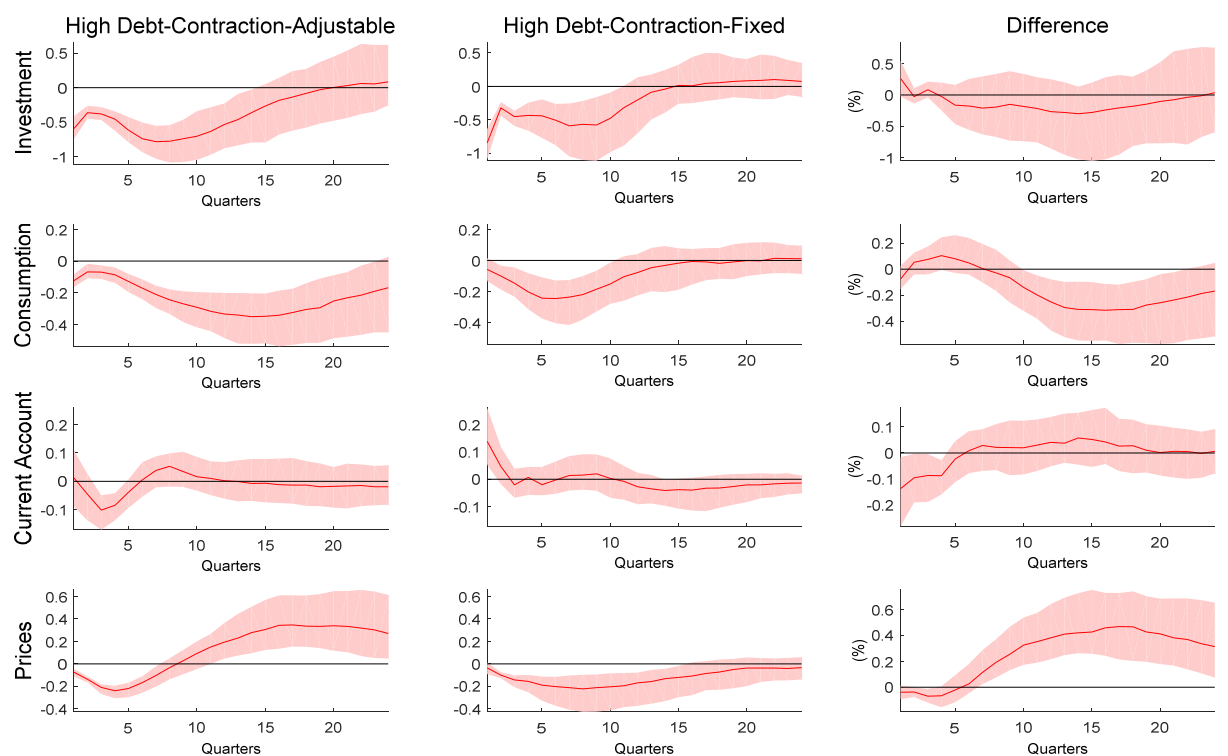

Notes: The gray shaded area depicts the variables and the horizon on which sign restrictions are imposed. The standard error bands which account for parameter uncertainty are the 16th and 84th percentiles of the set of accepted impulse response functions for all draws.

\subsection{Splitting the Sample using the Advanced Economies Exdusively}

We note that the sample, which holds predominantly adjustable rate loans, comprises the EMEs as well as the AEs while countries with a higher share of fixed rate loans are exclusively the AEs. We thus re-fit the model by splitting the sample by loan type with the EMEs excluded. The results are reported in Figure 18. We discover that the robustness check exhibits somewhat different responses from our baseline estimation. First, contractionary monetary shocks, on impact, have a stronger effect on consumption in a group with predominantly fixed rate loans. Nevertheless, the drop in consumption persists over time in the countries with predominantly 
Figure 18. Differences in Impulse Responses to a Monetary Policy Shock by Predominant Interest Type with High Household Debts at a Contractionary Monetary Policy Stance
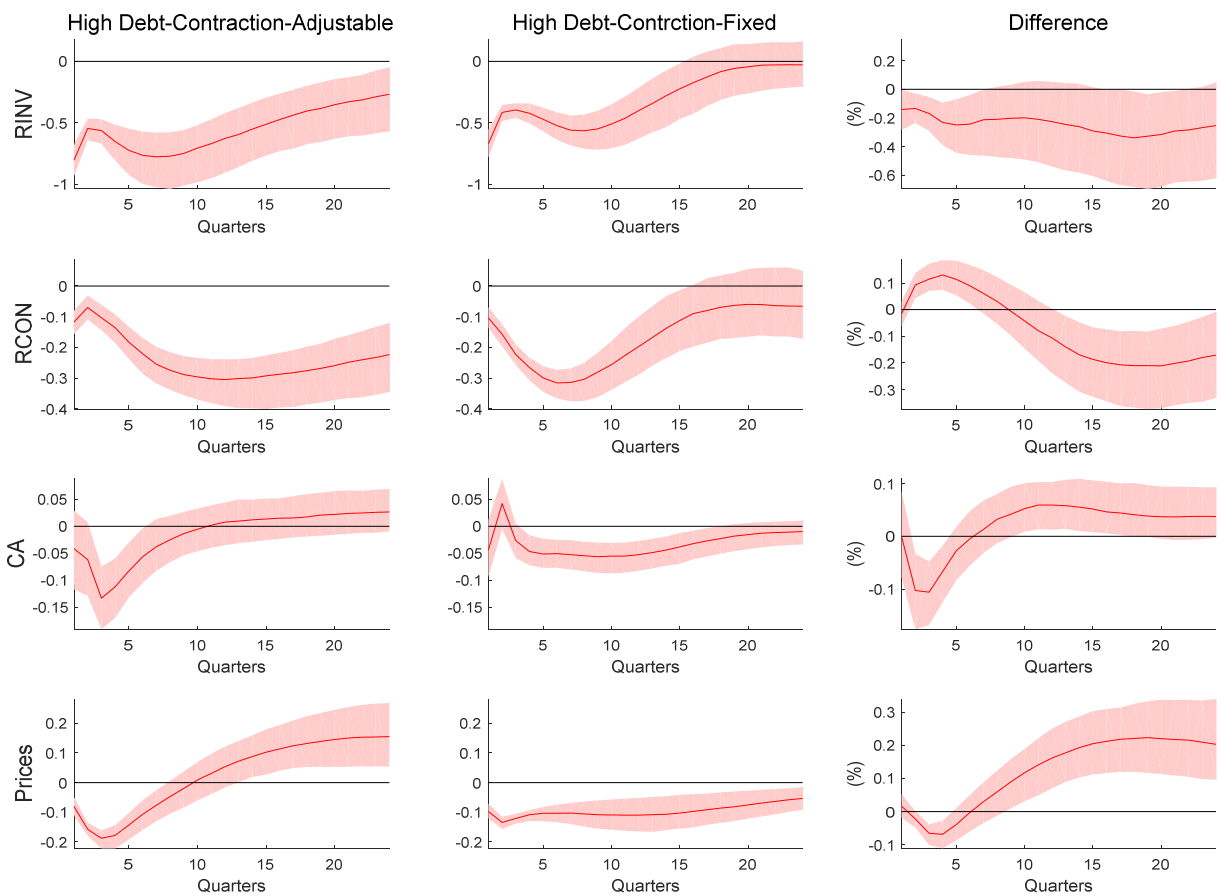

Notes: The gray shaded area depicts the variables and the horizon on 5 which sign restrictions are imposed. The standard error bands which account for parameter uncertainty are the 16th and 84th percentiles of the set of accepted impulse response functions for all draws.

adjustable rate loans while, in the other group, reverting rapidly to the original level. Interestingly, in the case of the response of prices, the difference is always statistically significant for prices; whereas the baseline estimation does not display any significant difference between the two groups. Prices respond more strongly to contractionary monetary shocks in countries having higher adjustable rate loans in short horizons while so in other groups in longer horizons. Our results are broadly consistent with those of our baseline estimations in terms of the effects of monetary shock on the real sector. 


\section{Conclusion}

We find that the effectiveness of monetary policy depends upon the degree of household indebtedness, using a panel of 28 countries. Specifically, the magnitude of responses of key macroeconomic variables to a monetary policy shock is greater in the state of high household debts. Furthermore, in order to investigate the possible asymmetry in the transmission of monetary policy shocks with opposite signs, we disentangle the effect of contractionary and expansionary monetary policy on the real economic activities in a high debt state. As the result, we find evidence that contractionary policy becomes more powerful 4 to 5 quarters after the impact than expansionary one is, especially in a high debt state. Finally, the effect of contractionary monetary policy in a high debt state is found to be more prominent in a country with a higher share of adjustable-rate household loans. These empirical findings lend support for the presence of cash-flow channel with respect to the transmission of monetary policy, in particular contractionary one.

Our study provide some interesting implications concerning the transmission of the monetary policy. Basically, our finding is broadly consistent with what the cash flow channel implies - monetary policy is more powerful when households are highly indebted and have adjustable rate contracts. Furthermore, this implies that the cash flow channel may be more responsive to contractionary policy stance. These results provide interesting and crucial implication that the policymakers need to take as many factors as possible into consideration in that a certain monetary policy action may have unexpected, differential consequences across states.

To our knowledge, this paper is the first attempt to investigate the dependence of the transmission of the monetary policy on the level of household indebtedness using the cross-country data. This paper also departs from existing literature in that the dependence itself may be affected by policy and market-structural factors such as monetary policy regime and share of floating interest rate loans. 
Our empirical work has left several important questions for future study. For example, more needs to be explored concerning why the asymmetric effects of monetary policy with opposite directions exist in a high debt state while not in a low debt state. Relatedly, the reason why the presence of the cash-flow channel in a high debt state is more prominent when monetary policy is contractionary remains to be further understood. 


\section{References}

Alpanda, S. and S. Zubairy (2016), "Household Debt Overhang and Transmission of Monetary Policy", mimeo, Texas A\&M University.

Angrist, Joshua D., Òscar Jordà, and Guido Kuersteiner (2013), "Semiparametric Estimates of Monetary Policy Effects: String Theory Revisited," National Bureau of Economic Research (NBER) Working Paper No. 19355.

Barnichon, R. and C. Matthes (2016), "Gaussian Mixture Approximations of Impulse Responses and the Nonlinear Effects of Monetary Shocks," Federal Reserve Bank of Richmond Working Paper No. 16-08, June 2016.

Beraja, M., A. Fuster, E. Hurst, and J. Vavra (2015), "Regional Heterogeneity and Monetary Policy," Federal Reserve Bank of New York Staff Report No. 731 .

Bernanke, B. and A. Blinder (1992), "The Federal Funds Rate and the Channels of Monetary Transmission," American Economic Review, Vol. 82 (September), pp. 901-21.

Bernanke, B. S., M. Gertler, and S. Gilchrist (1999), "The Financial Accelerator in a Quantitative Business Cycle Framework," Handbook of Macroeconomics, Vol. 1C ed. by J. B. Taylor and M. Woodford, pp. 1341-93. Amsterdam: Elsevier Science, North-Holland.

Bernanke, B. S. and I. Mihov (1998), "Measuring Monetary Policy," The Quarterly Journal of Economics, Vol. 113, No. 3, August, pp. 869-902.

Bernardini, M. and G. Peersman (2015), "Private Debt Overhang and the Government Spending Multiplier: Evidence for the United States," CESifo Working Paper Series No. 5284, CESifo Group Munich.

Bhutta, N., and B. J. Keys (2016), "Interest Rates and Equity Extraction during the Housing Boom,” American Economic Review, Vol. 106, pp. 1742-1774.

Calza, A., T. Monacelli, and L. Stracca, (2013), "Housing Finance and Monetary Policy," Journal of the European Economic Association, Vol. 11 (S1), pp. $101-122$. 
Cerutti, E., J. Dagher, and G. Dell'Ariccia (2015), "Housing Finance and Real-Estate Booms: A Cross-Country Perspective," IMF Staff Discussion Note, SDN/15/12, June 2015.

Chen, H., M. Michaux, and N. Roussanov (2013), "Houses as ATMs? Mortgage Refinancing and Macroeconomic Uncertainty," NBER Working Paper No. 19421.

Christiano, L. J., M. Eichenbaum, and C. L. Evans (1999), "Monetary Policies and Outcomes in the Post WWII U.S.," Handbook of Macroeconomics, Vol. 1, edited by John B. Taylor and Michael Woodford, Elsevier.

Cloyne, J., C. Ferreira, and P. Surico (2016), "Monetary Policy When Households Have Debt: New Evidence on the Transmission Mechanism," Bank of England Staff Working Paper No. 589.

Cover, James Peery (1992), "Asymmetric Effects of Positive and Negative Money-Supply Shocks.” Quarterly Journal of Economics, Vol. 107 (4), pp. 1261-82.

Drehmann, M. and K. Tsatsaronis (2014), "The Credit-to-GDP Gap and Countercyclical Capital Buffers: Questions and Answers," BIS Quarterly Review, Bank for International Settlements.

Flodén, M., M. Kilström, J. Sigurdsson, and R. Vestman (2016), "Household Debt and Monetary Policy: Revealing the Cash-Flow Channel," Swedish House of Finance Research Paper No. 16-8.

Fung, B. and M. Yuan (2001), "Measuring the Stance of Monetary Policy," mimeo, The Bank of Canada.

Garcia, René, and H. Schaller (2002), "Are the Effects of Monetary Policy Asymmetric?" Economic Inquiry, Vol. 40 (1), pp. 102-19.

Garriga, C., F. E. Kydland, and R. Sustek (2015), "Mortgages and Monetary Policy," Working Paper, Federal Reserve Bank of St. Louis.

Fry, R. and A. Pagan (2011), "Sign Restrictions in Structural Vector Autoregressions: A Critical Review," Journal of Economic Literature, Vol. 49, pp. 938-960. 
Iacoviello, M. (2005), "House Prices, Borrowing Constraints and Monetary Policy in the Business Cycle," American Economic Review, Vol. 95, pp. 739-764.

Jannsen, N., G. Potjagailo, and M. H. Wolters (2015), "Monetary Policy during Financial Crises: Is the Transmission Mechanism Impaired?" Kiel Working Papers No. 2005, August 2015.

Kiyotaki, N. and J. Moore (1997), "Credit Cycles," Journal of Political Economy, Vol. 105, pp. 211-48.

Lo, Ming Chien and J. Piger (2005), "Is the Response of Output to Monetary Policy Asymmetric? Evidence from a Regime-Switching Coefficients Model," Journal of Money, Credit and Banking, Vol. 37 (5), pp. 865-86.

Loayza, N. V. and C. Raddatz (2007), "The Structural Determinants of External Vulnerability," World Bank Economic Review, World Bank Group, Vol. 21 (3), pp. 359-87.

Mian, A. and A. Sufi (2014), "House Price Gains and U.S. Household Spending from 2002 to 2006," NBER Working Paper No. 20152.

Mian, A. and A. Sufi (2015), House of debt, University of Chicago Press.

Rubio, M. (2011), "Fixed- and Variable-Rate Mortgages, Business Cycles, and Monetary Policy," Journal of Money, Credit and Banking, Vol. 43 (4), pp. $657-688$.

Sá, F., P. Towbin, and T. Wieladek (2014), "Capital inflows, financial structure and housing booms," Journal of the European Economic Association, Vol. 12 (2), pp. 522-546.

Santoro, E, I. Petrella, D. Pfajfar, and Edoardo Gaffeo (2014), "Loss Aversion and the Asymmetric Transmission of Monetary Policy," Journal of Monetary Economics, November 2014, Vol. 68, pp. 19-36.

Smets, F. and G. Peersman (2001), "Are the Effects of Monetary Policy in the Euro Area Greaterin Recessions than in Booms?" European Central Bank Working Paper No. 52.

Tenreyro, S and G. Thwaites (2016), "Pushing on a string: US Monetary Policy Is Less Powerful in Recessions," American Economic Journal: 
Macroeconomics, Vol. 8, No. 4, pp. 43-74.

Thoma, M. A. (1994), "Subsample Instability and Asymmetries in Money-Income Causality," Journal of Econometrics, Vol. 64 (1-2), pp. 279-306.

Towbin, P. and S. Weber (2013), "Limits of Floating Exchange Rates: The Role of Foreign Currency Debt and Import Structure," Journal of Development Economics, Vol. 101, pp. 179-194.

Uhlig, H. (2005), "What Are the Effects of Monetary Policy on Output? Results from an Agnostic Identification Procedure," Journal of Monetary Economics, Vol. 52 (2), pp. 381-419.

Weise, Charles L. (1999), "The Asymmetric Effects of Monetary Policy: A Nonlinear Vector Autoregression Approach," Journal of Money, Credit and Banking, Vol. 31 (1), pp. 85-108. 


\section{$<$ Abstract in Korean>}

\section{가계부채 수준에 따른 통화정책의 파급효과}

\section{김영주 ${ }^{*}$ 임현준 ${ }^{*}$}

본고는 28개국의 1984 2015년 중 국가패널자료를 대상으로 교차패널 VAR모형을 이용하여 통화정책의 유효성이 가계부채 수준에 의해 어떻게 영 향을 받는지에 관한 분석을 시도하였다. 분석 결과, 통화정책 충격 발생 시 소비 및 고정투자가 가계부채가 높은 경우 더욱 크게 반응하는 것으로 나타 났다. 더 나아가 그러한 반응의 크기는 확장적 통화정책 기조에서보다 긴축 적 기조에서 더욱 두드러진 것으로 추정되었다. 아울러 긴축적 통화정책이 실물부문에 미치는 부정적 영향이 변동금리 대출 비중이 높은 국가에서 더 욱 두드러진 것으로 분석되었다. 이러한 분석 결과에 비추어 볼 때, 긴축적 통화정책의 파급경로에서 “현금흐름 경로”(cash flow channel)가 작용하는 것으로 판단된다.

핵심 주제어: GDP대비 가계부채 비율, 통화정책, 교차패널VAR, 고정금리대출 비중

JEL Classification: E52, E62, R38

* 한국은행 경제연구원 거시경제연구실 연구위원 (전화: 02-759-5475, E-mail: econoky@bok.or.kr) ** 한국은행 경제연구원 국제경제연구실 연구위원 (전화: 02-759-5427, E-mail: limhj1@bok.or.kr) 


\section{$\mathrm{BOK}$ 경제연구 발간목록}

한국은행 경제연구원에서는 Working Paper인 『BOK 경제연구』를 수시로 발간하고 있습니다. ${ }^{『} \mathrm{BOK}$ 경제연구』는 주요 경제 현상 및 정책 효과에 대한 직관적 설명 뿐 아니라 깊이 있는 이론 또는 실증 분석을 제공함으로써 엄밀한 논증에 초점을 두는 학술논문 형태의 연구이며 한국은행 직원 및 한국은행 연구용역사업의 연구 결과물이 수록되고 있습니다.

『BOK 경제연구』는 한국은행 경제연구원 홈페이지(http://imer.bok.or.kr)에서 다운로드하여 보실 수 있습니다.

\section{제2014-1 Network Indicators for Monitoring} Intraday Liquidity in BOK-Wire+

2 중소기업에 대한 신용정책 효과

3 경제충격 효과의 산업간 공행성 분석

4 서비스업 발전을 통한 내외수 균형성장: 기대효과 및 리스크

5 Cross-country-heterogeneous and Time-varying Effects of Unconventional Monetary Policies in AEs on Portfolio Inflows to EMEs

6 인터넷뱅킹, 결제성예금 및 은행 수익성과의 관계 분석

7 Dissecting Foreign Bank Lending Behavior During the 2008-2009 Crisis

8 The Impact of Foreign Banks on Monetary Policy Transmission during the Global Financial Crisis of 2008-2009: Evidence from Korea

9 Welfare Cost of Business Cycles in Economies with Individual Consumption Risk

10 Investor Trading Behavior Around the Time of Geopolitical Risk Events: Evidence from South Korea

11 Imported-Inputs Channel of Exchange Rate Pass-Through: Evidence from Korean Firm-Level Pricing Survey
Seungjin Baek •

Kimmo Soram ki • Jaeho Yoon

정호성·임호성

황선웅 - 민성환 ·

신동현·김기호

김승원 · 황광명

Kyoungsoo Yoon •

Christophe Hurlin

이동규·전봉걸

Moon Jung Choi •

Eva Gutierrez •

Maria Soledad Martinez Peria

Bang Nam Jeon •

Hosung Lim $\cdot$ Ji Wu

Martin Ellison •

Thomas J. Sargent

Young Han Kim •

Hosung Jung

Jae Bin Ahn •

Chang-Gui Park 


\begin{tabular}{|c|c|c|}
\hline 제2014-12 & 비대칭 금리기간구조에 대한 실증분석 & 김기호 \\
\hline 13 & $\begin{array}{l}\text { The Effects of Globalization } \\
\text { on Macroeconomic Dynamics } \\
\text { in a Trade-Dependent Economy: } \\
\text { the Case of Korea }\end{array}$ & Fabio Milani · Sung Ho Park \\
\hline 14 & $\begin{array}{l}\text { 국제 포트폴리오투자 행태 분석: 채권-주식 } \\
\text { 투자자금간 상호관계를 중심으로 }\end{array}$ & 이주용·김근영 \\
\hline 15 & $\begin{array}{l}\text { 북한 경제의 추격 성장 가능성과 } \\
\text { 정책 선택 시나리오 }\end{array}$ & 이근 · 최지영 \\
\hline 16 & $\begin{array}{l}\text { Mapping Korea's International Linkages } \\
\text { using Generalised Connectedness Measures }\end{array}$ & Hail Park $\cdot$ Yongcheol Shin \\
\hline 17 & $\begin{array}{l}\text { 국제자본이동 하에서 환율신축성과 } \\
\text { 경상수지 조정: 국가패널 분석 }\end{array}$ & 김근영 \\
\hline 18 & $\begin{array}{l}\text { 외국인 투자자가 외환시장과 주식시장 간 } \\
\text { 유동성 동행화에 미치는 영향 }\end{array}$ & 김준한 $\cdot$ 이지은 \\
\hline 19 & $\begin{array}{l}\text { Forecasting the Term Structure } \\
\text { of Government Bond Yields } \\
\text { Using Credit Spreads and Structural Breaks }\end{array}$ & $\begin{array}{l}\text { Azamat Abdymomunov } \\
\text { Kyu Ho Kang } \\
\text { Ki Jeong Kim }\end{array}$ \\
\hline 20 & $\begin{array}{l}\text { Impact of Demographic Change } \\
\text { upon the Sustainability of Fiscal Policy }\end{array}$ & $\begin{array}{l}\text { Younggak Kim· } \\
\text { Myoung Chul Kim } \\
\text { Seongyong Im }\end{array}$ \\
\hline 21 & $\begin{array}{l}\text { The Impact of Population Aging } \\
\text { on the Countercyclical Fiscal Stance in Korea, } \\
\text { with a Focus on the Automatic Stabilizer }\end{array}$ & $\begin{array}{l}\text { Tae-Jeong Kim } \cdot \\
\text { Mihye Lee } \cdot \text { Robert Dekle }\end{array}$ \\
\hline 22 & $\begin{array}{l}\text { 미 연준과 유럽중앙은행의 비전통적 통화정책 } \\
\text { 수행원칙에 관한 고찰 }\end{array}$ & 김병기· 김진일 \\
\hline 23 & $\begin{array}{l}\text { 우리나라 일반인의 인플레이션 기대 형성 } \\
\text { 행태 분석 }\end{array}$ & 이한규·최진호 \\
\hline
\end{tabular}


제2014-24 Nonlinearity in Nexus between

Working Hours and Productivity

25 Strategies for Reforming Korea's Labor Market to Foster Growth

26 글로벌 금융위기 이후 성장잠재력 확충: 2014 한국은행 국제컨퍼런스 결과보고서

27 인구구조 변화가 경제성장률에 미치는 영향: 자본이동의 역할에 대한 논의를 중심으로

28 Safe Assets

29 확장된 실업지표를 이용한 우리나라 노동시장에서의 이력현상 분석

Entropy of Global Financial Linkages

31 International Currencies Past, Present and Future: Two Views from Economic History

32 금융체제 이행 및 통합 사례:

남북한 금융통합에 대한 시사점

Measuring Price-Level Uncertainty and Instability in the U.S., 1850-2012

고용보호제도가 노동시장 이원화

및 노동생산성에 미치는 영향

35 해외충격시 외화예금의 역할 : 주요 신흥국 신용스프레드에 미치는 영향을 중심으로 Emerging Market Economies, and Their Policy Responses
Dongyeol Lee •

Hyunjoon Lim

Mai Dao · Davide Furceri ·

Jisoo Hwang .

Meeyeon Kim •

Tae-Jeong Kim

한국은행 경제연구원

손종칠

Robert J. Barro

김현학 · 황광명

Daeyup Lee

Barry Eichengreen

김병연

Timothy Cogley •

Thomas J. Sargent

김승원

정호성 - 우준명

김인수 · 이명수

황광명 · 김경민 ·

노충식·김미진

Woon Gyu Choi •

Taesu Kang •

Geun-Young Kim •

Byongju Lee 
제2015-1 글로벌 금융위기 이후 주요국

통화정책 운영체계의 변화

2 미국 장기시장금리 변동이 우리나라 금리기간구조에 미치는 영향 분석 및 정책적 시사점

3 직간접 무역연계성을 통한 해외충격의 우리나라 수출입 파급효과 분석

4 통화정책 효과의 지역적 차이

5 수입중간재의 비용효과를 고려한 환율변동과 수출가격 간의 관계

6 중앙은행의 정책금리 발표가 주식시장 유동성에 미치는 영향

7 은행 건전성지표의 변동요인과 거시건전성 규제의 영향

8 Price Discovery and Foreign Participation in The Republic of Korea's Government Bond Futures and Cash Markets

9 규제가 노동생산성에 미치는 영향:

한국의 산업패널 자료를 이용한 실증분석

10 인구 고령화와 정년연장 연구

(세대 간 중첩모형(OLG)을 이용한 정량 분석)

11 예측조합 및 밀도함수에 의한 소비자물가 상승률 전망

12 인플레이션 동학과 통화정책

13 Failure Risk and the Cross-Section of Hedge Fund Returns

14 Global Liquidity and Commodity Prices

15 Foreign Ownership, Legal System and Stock Market Liquidity
김병기·김인수

강규호·오형석

최문정·김근영

김기호

김경민

이지은

강종구

Jaehun Choi - Hosung Lim •

Rogelio Jr. Mercado •

Cyn-Young Park

이동렬· 최종일·이종한

홍재화 - 강태수

김현학

우준명

Jung-Min Kim

Hyunju Kang •

Bok-Keun $\mathrm{Yu}$.

Jongmin $\mathrm{Yu}$

Jieun Lee $\cdot$ Kee H. Chung 
제2015-16 바젤피 은행 경기대응완충자본 규제의 기준지표에 대한 연구

17 우리나라 대출 수요와 공급의 변동요인 분석

18 북한 인구구조의 변화 추이와 시사점

19 Entry of Non-financial Firms and Competition in the Retail Payments Market

20 Monetary Policy Regime Change and Regional Inflation Dynamics: Looking through the Lens of Sector-Level Data for Korea

21 Costs of Foreign Capital Flows in Emerging Market Economies: Unexpected Economic Growth and Increased Financial Market Volatility

22 글로벌 금리 정상화와 통화정책 과제: 2015년 한국은행 국제컨퍼런스 결과보고서

23 The Effects of Global Liquidity on Global Imbalances

24 실물경기를 고려한 내재 유동성 측정

25 Deflation and Monetary Policy

26 Macroeconomic Shocks and Dynamics of Labor Markets in Korea

27 Reference Rates and Monetary Policy Effectiveness in Korea

29 An Analysis of Trade Patterns in East Asia and the Effects of the Real Exchange Rate Movements

30 Forecasting Financial Stress Indices in Korea: A Factor Model Approach
서현덕·이정연

강종구 · 임호성

최지영

Jooyong Jun

Chi-Young Choi •

Joo Yong Lee

Roisin O'Sullivan

Kyoungsoo Yoon • Jayoung Kim

한국은행 경제연구원

Marie-Louise DJIGBENOU-KRE •

Hail Park

우준명·이지은

Barry Eichengreen

Tae Bong Kim •

Hangyu Lee

Heung Soon Jung •

Dong Jin Lee.

Tae Hyo Gwon .

Se Jin Yun

Bongseok Choi •

Wooyoung Park.

Bok-Keun Yu

Moon Jung Choi

Geun-Young Kim • Joo Yong Lee

Hyeongwoo Kim $\cdot$ Hyun Hak Kim. Wen Shi 


\begin{tabular}{|c|c|c|}
\hline 제2016 -1 & $\begin{array}{l}\text { The Spillover Effects of U.S. Monetary } \\
\text { Policy on Emerging Market Economies: } \\
\text { Breaks, Asymmetries and Fundamentals }\end{array}$ & $\begin{array}{l}\text { Geun-Young Kim } \cdot \\
\text { Hail Park· } \\
\text { Peter Tillmann }\end{array}$ \\
\hline 2 & $\begin{array}{l}\text { Pass-Through of Imported Input Prices to } \\
\text { Domestic Producer Prices: Evidence from } \\
\text { Sector-Level Data }\end{array}$ & $\begin{array}{l}\text { JaeBin Ahn } \\
\text { Chang-Gui Park } \\
\text { Chanho Park }\end{array}$ \\
\hline 3 & $\begin{array}{l}\text { Spillovers from U.S. Unconventional } \\
\text { Monetary Policy and Its Normalization } \\
\text { to Emerging Markets: A Capital Flow } \\
\text { Perspective }\end{array}$ & $\begin{array}{l}\text { Sangwon Suh } \\
\text { Byung-Soo Koo }\end{array}$ \\
\hline 4 & $\begin{array}{l}\text { Stock Returns and Mutual Fund Flows } \\
\text { in the Korean Financial Market: } \\
\text { A System Approach }\end{array}$ & $\begin{array}{l}\text { Jaebeom Kim } \\
\text { Jung-Min Kim }\end{array}$ \\
\hline 5 & $\begin{array}{l}\text { 정책금리 변동이 성별·세대별 고용률에 } \\
\text { 미치는 영향 }\end{array}$ & 정성엽 \\
\hline 6 & $\begin{array}{l}\text { From Firm-level Imports to } \\
\text { Aggregate Productivity: Evidence } \\
\text { from Korean Manufacturing Firms Data }\end{array}$ & $\begin{array}{l}\text { JaeBin Ahn } \\
\text { Moon Jung Choi }\end{array}$ \\
\hline 7 & $\begin{array}{l}\text { 자유무역협정(FTA)이 한국 기업의 } \\
\text { 기업내 무역에 미친 효과 }\end{array}$ & 전봉걸·김은숙·이주용 \\
\hline 8 & $\begin{array}{l}\text { The Relation Between Monetary and } \\
\text { Macroprudential Policy }\end{array}$ & Jong Ku Kang \\
\hline 9 & $\begin{array}{l}\text { 조세피난처 투자자가 투자 기업 및 주식 } \\
\text { 시장에 미치는 영향 }\end{array}$ & 정호성·김순호 \\
\hline 10 & $\begin{array}{l}\text { 주택실거래 자료를 이용한 주택부문 거시 } \\
\text { 건전성 정책 효과 분석 }\end{array}$ & 정호성·이지은 \\
\hline 11 & $\begin{array}{l}\text { Does Intra-Regional Trade Matter in } \\
\text { Regional Stock Markets?: New Evidence } \\
\text { from Asia-Pacific Region }\end{array}$ & $\begin{array}{l}\text { Sei-Wan Kim } \cdot \\
\text { Moon Jung Choi }\end{array}$ \\
\hline 12 & $\begin{array}{l}\text { Liability, Information, and Anti-fraud } \\
\text { Investment in a Layered Retail } \\
\text { Payment Structure }\end{array}$ & $\begin{array}{l}\text { Kyoung-Soo Yoon } \\
\text { Jooyong Jun }\end{array}$ \\
\hline 13 & $\begin{array}{l}\text { Testing the Labor Market Dualism in } \\
\text { Korea }\end{array}$ & $\begin{array}{l}\text { Sungyup Chung. } \\
\text { Sunyoung Jung }\end{array}$ \\
\hline 14 & $\begin{array}{l}\text { 북한 이중경제 사회계정행렬 추정을 통한 } \\
\text { 비공식부문 분석 }\end{array}$ & 최지영 \\
\hline
\end{tabular}




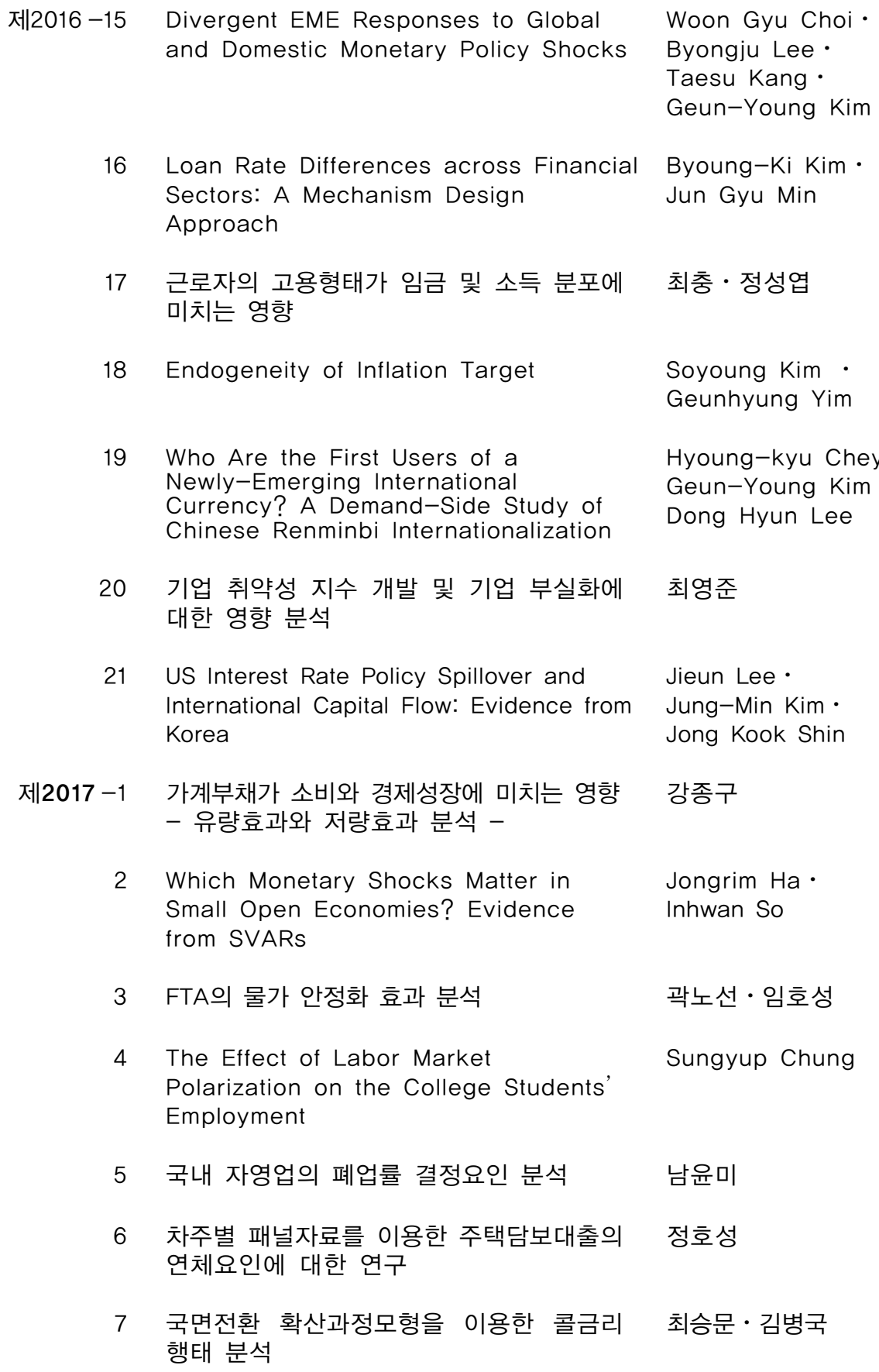

20 기업 취약성 지수 개발 및 기업 부실화에 최영준 대한 영향 분석

21 US Interest Rate Policy Spillover and International Capital Flow: Evidence from Korea

Jieun Lee $\cdot$

Jung-Min Kim •

Jong Kook Shin

제2017-1 가계부채가 소비와 경제성장에 미치는 영향 강종구

- 유량효과와 저량효과 분석 -

2 Which Monetary Shocks Matter in Small Open Economies? Evidence from SVARs

Jongrim $\mathrm{Ha} \cdot$ Inhwan So

3 FTA의 물가 안정화 효과 분석

곽노선·임호성

4 The Effect of Labor Market Polarization on the College Students'

Sungyup Chung Employment

5 국내 자영업의 폐업률 결정요인 분석 남윤미

6 차주별 패널자료를 이용한 주택담보대출의 정호성 연체요인에 대한 연구

7 국면전환 확산과정모형을 이용한 콜금리 최승문·김병국 행태 분석 


\begin{tabular}{|c|c|c|}
\hline 제2017 -8 & $\begin{array}{l}\text { Behavioral Aspects of Household } \\
\text { Portfolio Choice: Effects of Loss } \\
\text { Aversion on Life Insurance Uptake } \\
\text { and Savings }\end{array}$ & In Do Hwang \\
\hline 9 & 신용공급 충격이 재화별 소비에 미치는 영향 & 김광환 · 최석기 \\
\hline 10 & 유가가 손익분기인플레이션에 미치는 영향 & 김진용 - 김준철 - 임형준 \\
\hline 11 & $\begin{array}{l}\text { 인구구조변화가 인플레이션의 장기 추세에 } \\
\text { 미치는 영향 }\end{array}$ & 강환구 \\
\hline 12 & $\begin{array}{l}\text { 종합적 상환여건을 반영한 과다부채 } \\
\text { 가계의 리스크 요인 분석 }\end{array}$ & 이동진·한진현 \\
\hline 13 & $\begin{array}{l}\text { Crowding out in a Dual Currency Regime? } \\
\text { Digital versus Fiat Currency }\end{array}$ & $\begin{array}{l}\text { KiHoon Hong } \cdot \\
\text { Kyounghoon Park } \\
\text { Jongmin } \mathrm{Yu}\end{array}$ \\
\hline 14 & $\begin{array}{l}\text { Improving Forecast Accuracy of } \\
\text { Financial Vulnerability: Partial Least } \\
\text { Squares Factor Model Approach }\end{array}$ & $\begin{array}{l}\text { Hyeongwoo Kim• } \\
\text { Kyunghwan Ko }\end{array}$ \\
\hline 15 & $\begin{array}{l}\text { Which Type of Trust Matters?: } \\
\text { Interpersonal vs. Institutional vs. } \\
\text { Political Trust }\end{array}$ & In Do Hwang \\
\hline 16 & 기업특성에 따른 연령별 고용행태 분석 & 이상욱·권철우·남윤미 \\
\hline 17 & $\begin{array}{l}\text { Equity Market Globalization and } \\
\text { Portfolio Rebalancing }\end{array}$ & $\begin{array}{l}\text { Kyungkeun Kim } \\
\text { Dongwon Lee }\end{array}$ \\
\hline 18 & $\begin{array}{l}\text { The Effect of Market Volatility on } \\
\text { Liquidity and Stock Returns in the } \\
\text { Korean Stock Market }\end{array}$ & Jieun Lee $\cdot \mathrm{KeeH}$.Chung \\
\hline 19 & $\begin{array}{l}\text { Using Cheap Talk to Polarize or Unify } \\
\text { a Group of Decision Makers }\end{array}$ & Daeyoung Jeong \\
\hline 20 & $\begin{array}{l}\text { 패스트트랙 기업회생절차가 법정관리 기업의 } \\
\text { 이자보상비율에 미친 영향 }\end{array}$ & 최영준 \\
\hline 21 & 인구고령화가 경제성장에 미치는 영향 & 안병권·김기호·육승환 \\
\hline 22 & $\begin{array}{l}\text { 고령화에 대응한 인구대책: OECD사례를 중심 } \\
\text { 으로 }\end{array}$ & 김진일·박경훈 \\
\hline
\end{tabular}




\begin{tabular}{|c|c|c|}
\hline 제2017 -23 & 인구구조변화와 경상수지 & 김경근·김소영 \\
\hline 24 & 통일과 고령화 & 최지영 \\
\hline 25 & 인구고령화가 주택시장에 미치는 영향 & $\begin{array}{l}\text { 오강현·김솔·윤재준· } \\
\text { 안상기·권동휘 }\end{array}$ \\
\hline 26 & 고령화가 대외투자에 미치는 영향 & 임진수·김영래 \\
\hline 27 & $\begin{array}{l}\text { 인구고령화가 가계의 자산 및 부채에 } \\
\text { 미치는 영향 }\end{array}$ & 조세형·이용민 · 김정훈 \\
\hline 28 & $\begin{array}{l}\text { 인구고령화에 따른 우리나라 산업구조 } \\
\text { 변화 }\end{array}$ & 강종구 \\
\hline 29 & 인구구조 변화와 재정 & 송호신·허준영 \\
\hline 30 & 인구고령화가 노동수급에 미치는 영향 & 이철희·이지은 \\
\hline 31 & 인구 고령화가 금융산업에 미치는 영향 & $\begin{array}{l}\text { 윤경수·차재훈·박소희 } \\
\text { 강선영 }\end{array}$ \\
\hline 32 & 금리와 은행 수익성 간의 관계 분석 & 한재준 · 소인환 \\
\hline 33 & $\begin{array}{l}\text { Bank Globalization and Monetary } \\
\text { Policy Transmission in Small Open } \\
\text { Economies }\end{array}$ & Inhwan So \\
\hline 34 & $\begin{array}{l}\text { 기존 경영자 관리인(DIP) 제도의 회생기업 } \\
\text { 경영성과에 대한 영향 }\end{array}$ & 최영준 \\
\hline 35 & $\begin{array}{l}\text { Transmission of Monetary Policy in } \\
\text { Times of High Household Debt }\end{array}$ & $\begin{array}{l}\text { Youngju Kim• } \\
\text { Hyunjoon Lim }\end{array}$ \\
\hline
\end{tabular}

